SŁawomir Dorocki, PaweŁ Brzegowy

Uniwersytet Pedagogiczny, Kraków, Polska

\title{
Przekształcenia struktury gospodarki departamentów zamorskich Francji jako konsekwencja światowego kryzysu gospodarczego
}

\section{Transformations of the economic structure of the overseas departments of France as a consequence of the global economic crisis}

\begin{abstract}
Streszczenie: Celem pracy jest zobrazowanie przemian w zróżnicowaniu struktury gospodarczej w departamentach i regionach Francji pozaeuropejskiej DOM (Gwadelupa, Martynika, Gujana Francuska i Réunion) na tle Francji metropolitalnej, w warunkach światowego kryzysu gospodarczego. Podjęta została próba odpowiedzi na pytanie: czy i w jakim stopniu kryzys finansowy 2008 r. wpłynął na gospodarki zamorskie oraz w jakim zakresie dostrzegalne od kilkunastu lat zmiany w strukturze produkcji przemysłowej i usług DROM, w tym we wdrażaniu trzeciej fazy rewolucji przemysłowej, zostały zaburzone w następstwie wzmiankowanej dekoniunktury? Odzwierciedleniem postępujących przekształceń w departamentach zamorskich Francji jest sukcesywne redukowanie zatrudnienia w rolnictwie na rzecz przemysłu i usług, w tym rozwój technologies de pointe (przemysłu wysokiej technologii). Przykładem tych zmian jest rozwijany od lat 60 . XX w. przemysł turystyczny, który współcześnie próbuje się przeobrazić w fundamentalny substrat gospodarek Francji pozaeuropejskiej. Na potrzeby zilustrowania poziomu aktywności ekonomicznej DROM analizie poddano wzrost wielkości bezrobocia oraz zmiany w zakresie i strukturze zatrudnienia, w tym zróżnicowanie samozatrudnienia, oraz przedstawiono skalę bankructw przedsiębiorstw w okresie przed i po $2008 \mathrm{r}$.
\end{abstract}

Abstract: The intention of the article is to present the transformations in the diversification of the economic structures in overseas France, the DOM-TOM (Guadeloupe, Martinique, French Guiana and Reunion) in comparison to metropolitan France, during the global economic crisis. This article is an attempt to answer the question: whether, and to what extentthe financial crisis of 2008 has affected the overseas economy and to what extent the changes that were observable in the last several years in the industrial production structure and services such as the third phase of the industrial revolution, have been affected in the aftermath of the global recession. Reflection of the progressive transformation in the overseas departments of France is the gradual reduction of employment in agriculture and growing employment in industry and services as well as the development of technologies de pointe (high-tech industry). An example of these changes is the tourism industry developed since the 1960s, that today is trying to become the fundamental substrate of the economies of the Overseas France. In order to illus- 
trate the economic activity of these territories, the following factors were analysed: the increase in the unemployment rates and changes in size and structure of employment, including changes in the volume of self-employment and business bankruptcies during the period before and after 2008 .

Słowa kluczowe: bezrobocie; departamenty zamorskie; Francja; gospodarka; kryzys finansowy; regiony; samozatrudnienie

Keywords: economy; financial crisis; France; overseas departments; regions; self-employment; unemployment

\section{WSTĘP}

Wedle zapisów ustawy z 19 marca 1946 r. ${ }^{1}$ i Konstytucji IV Republiki z 27 października tego samego roku, z grupy byłych kolonii francuskich wydzielono departamenty zamorskie (départements d'outre-mer, DOM). Cztery dotychczasowe tzw. stare kolonie (vieilles colonies): Gwadelupę, Martynikę, Gujanę Francuską oraz Réunion, uczyniono integralną częścią państwa francuskiego. Obok DOM funkcjonowały wtenczas również terytoria zamorskie (territoires d'outre-mer, TOM), państwa stowarzyszone (états associés), a także terytoria stowarzyszone Kamerun i Togo. Wskazane jednostki, wraz z departamentami algierskimi i Francją kontynentalną, tworzyły istniejącą do 1958 r. Unię Francuską, która pozostawała sukcesorką francuskiego imperium kolonialnego. Wsparta na równości praw i obowiązków oraz tolerancji etnicznej i religijnej, Unia miała zagwarantować dalszy rozwój cywilizacyjny oraz zapewnić dobrobyt gospodarczy i bezpieczeństwo partycypujących w niej narodów. Wskutek reformy konstytucyjnej z 28 marca 2003 r. termin TOM ostatecznie wykreślono z porządku konstytucyjnego. Francję pozaeuropejską podzielono na DOM, wspólnoty zamorskie (collectivités d'outre-mer, COM), Francuskie Terytoria Południowe i Antarktyczne, Wyspę Clippertona oraz Nową Kaledonię, będącą wspólnotą sui generis. Ponieważ każdy z DOM jest również regionem zamorskim (région d'outre-mer, ROM), toteż najczęściej określa się je skrótowcem DROM (Desse, 2013). W 2011 r. w następstwie wcześniejszego referendum do grona DOM dołączyła Majotta. Artykuł 349 Traktatu o funkcjonowaniu Unii Europejskiej zakwalifikował DROM do regionów najbardziej oddalonych (régions ultrapériphériques, RUP), traktowanych jako obszary specjalne państw członkowskich UE. W wyniku egzemplarycznej sytuacji społeczno-gospodarczej rzeczonych obszarów, spowodowanej w szczególności przez ich oddalenie geograficzne, stosowaniu prawa wspólnotowego na ich terytoriach towarzyszą pewne odstępstwa (Priollaud, Siritzky, 2008). Za pośrednictwem RUP rynek wspólnotowy zwiększył różnorodność, zaś granice UE zyskały rozleglejszy, kosmopolityczny wymiar.

Pod względem średniego wieku ludności DROM przynależą do najmłodszych regionów Francji. Trzecia część populacji ma mniej niż 25 lat (Martynika i Gwadelupa) oraz stanowi 41\% mieszkańców w Réunion i 51\% w Gujanie Francuskiej. Pośród najważniejszych problemów społeczno-ekonomicznych DROM w pierwszej kolejności należy zważyć na

${ }^{1}$ Loi n ${ }^{\circ}$ 46-451 du 19 mars 1946 tendant au classement comme départements français de la Guadeloupe, de la Martinique, de la Réunion et de la Guyane française. 
wysoką stopę bezrobocia, która osiągnęła poziom 50\% wśród ludzi młodych, w większości niewykształconych. Na uwagę zasługują ponadto antagonizmy wynikające ze zróżnicowania narodowościowego DROM. Kongruentnym ich przykładem jest Gujana Francuska, zamieszkiwana przez 25 grup narodowościowych, z językiem urzędowym francuskim i mówionym kreolskim (podzielonym na dialekty). Konsekwencją etnicznej wielości jest kreolizacja, rozumiana jako interakcyjna konsolidacja w jednym miejscu elementów kultury europejskiej, azjatyckiej, afrykańskiej i karaibskiej (Bernabé i in., 1993). Globalny kryzys finansowy 2008 r. spowodował, iż DROM we Francji kontynentalnej jeszcze w większym stopniu poczęto postrzegać jako kosztowny kolonialny dodatek do metropolii. Zainicjowane w styczniu 2009 r. w Antylach Francuskich strajki ukazały skalę społecznego niezadowolenia Francuzów zamorskich, żądających wzrostu płacy minimalnej, obniżki cen paliw i żywności oraz przeciwdziałania przestępczości (Almar, 2012).

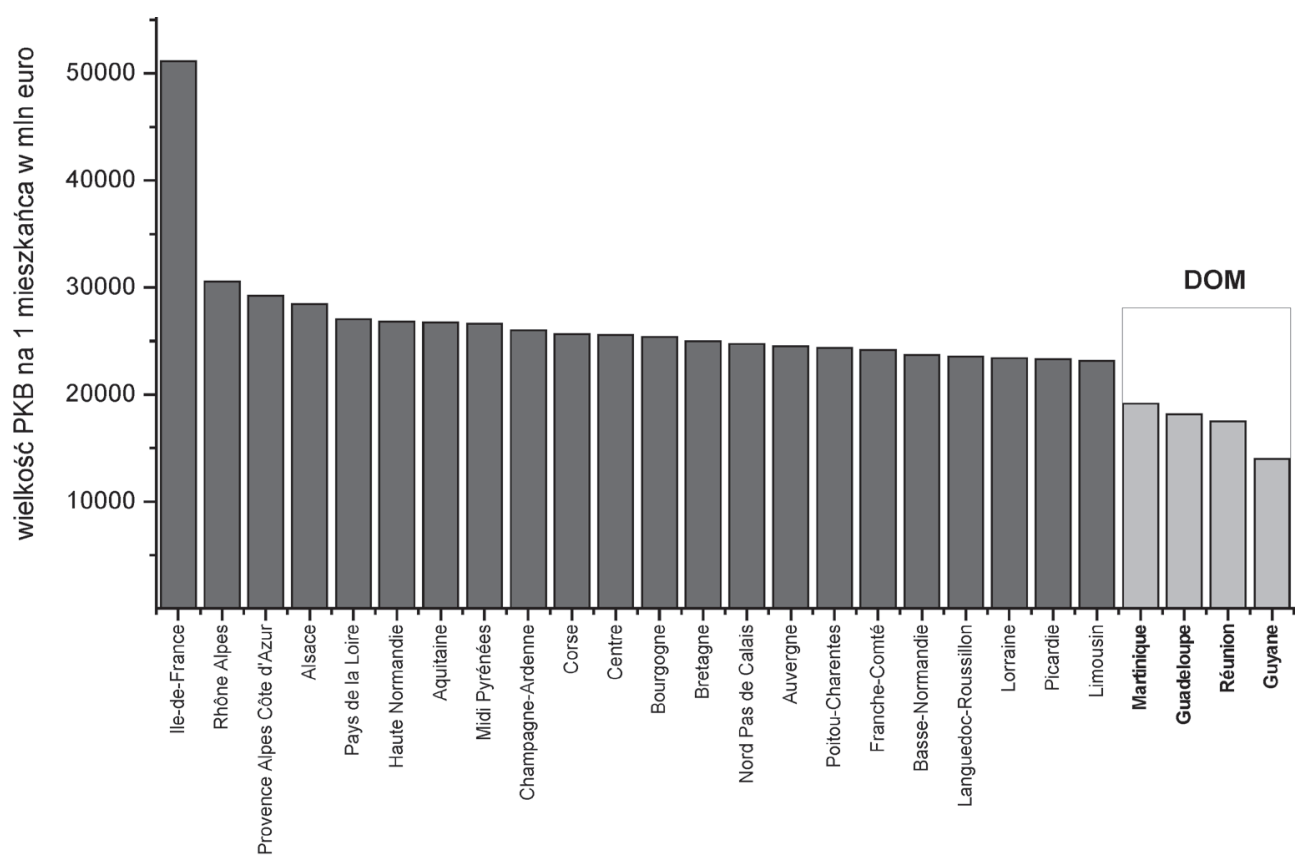

Ryc. 1. Wielkość PKB na 1 mieszkańca w regionach Francji w 2012 r.

Źródło: opracowanie własne na podstawie danych INSEE

Celem artykułu jest analiza sytuacji społeczno-gospodarczej departamentów zamorskich Francji w okresie światowego kryzysu gospodarczego. Opisu zmian dokonano na podstawie wybranych danych statystycznych zaczerpniętych z baz danych: INSEE (National Institute of Statistics and Economic Studies), Eurostat, Dgcis (Direction générale de la compétitivité, de l'industrie et des service). We wnioskowaniu o transformacjach zachodzących w DOM i regionach Francji metropolitalnej w okresie kryzysu uwzględniono zmiany udziału osób bezrobotnych oraz wzrost obciążenia osób pracujących niepracującymi (współczynnik obciążenia 
ekonomicznego). Innymi wykorzystanymi wskaźnikami są liczba upadłości i likwidacji firm na tle przedsiębiorstw nowo powstałych oraz wielkość samozatrudnienia jako odpowiedź na wzrost bezrobocia i upadek firm. W analizie uwzględniono również zmiany w strukturze zatrudnienia, w perspektywie przemian dokonujących się w globalnej gospodarce w aspekcie rozwoju gospodarki opartej na wiedzy. Należy jednak zwrócić uwagę, że kryzys światowy jest tylko jednym z czynników oddziałujących na przemiany struktury gospodarek poszczególnych państw i regionów świata i w różnym stopniu wpływa na funkcjonowanie poszczególnych ich sektorów (Rachwał, 2011; Zdon-Korzeniowska, Rachwał, 2011).

\section{Bezrobocie}

Światowy kryzys finansowy, oddziałując na globalny obieg strumieni finansowych i produktów w gospodarce, spowodował pogorszenie sytuacji ekonomicznej w większości regionów świata (Kilar, 2011). Ograniczenie podaży kapitału przez instytucje bankowe doprowadziło do zahamowania inwestycji przedsiębiorstw oraz spadku konsumpcji w gospodarstwach domowych (Zioło, 2011). Konsekwencją tej sytuacji było spowolnienie rozwoju gospodarczego, a następnie recesja, w wyniku której nastąpił spadek zatrudnienia i wzrost bezrobocia (Dorocki, 2011).

Udział bezrobocia w departamentach zamorskich Francji na początku XXI w. wykazywał tendencję spadkową z 26\% w 2001 r. do 23\% w 2007 r. Wraz z początkiem kryzysu światowego zauważalny jest wzrost (ponad 2\%) udziału bezrobotnych w DOM, trwający do 2010 r., który to poziom z nieznacznym spadkiem utrzymywał się do 2012 r. (ryc. 2). W odniesieniu do poszczególnych regionów wszystkie one odnotowały w okresie 20072008 wzrost bezrobocia. Jednakże najwyższy był on w przypadku Réunion, w którym, po okresie gwałtownego spadku z 32\% do 25\% w latach 2004-2007, nastąpił wzrost do ponad $29 \%$ w $2011 \mathrm{r}$. W pozostałych przypadkach wzrost bezrobocia nie przekroczył poziomu 2\%. W Gujanie Francuskiej, pomimo niewielkiego podwyższenia wskaźnika bezrobocia w 2008 r., można było obserwować spadek udziału osób niepracujących trwający do 2010 r.

Porównując zmiany w udziale bezrobotnych w departamentach zamorskich i regionach Francji kontynentalnej, godzi się odnotować, że we wszystkich regionach europejskich zmiany te w okresie kryzysu wykazywały większą zgodność niż w przypadku DOM. Ogólnie wartość bezrobocia na kontynencie była prawie dwa razy niższa niż w DOM i od 2008 r. następował utrzymujący się wzrost bezrobocia. Eskalacja ta, podobnie jak w DOM, wyniosła ok. 2\%. Wyraźną różnicę stanowił natomiast ciągły wzrost bezrobocia w większości regionów Francji kontynentalnej. Jedynym regionem z tendencją spadkową bezrobocia pozostawał Franche-Comté, co było wynikiem jego ożywionego rozwoju gospodarczego. Głównym potencjałem Franche-Comté jest przemysł dóbr kapitałowych, m.in. sprzętu elektrycznego i elektronicznego, produkcja rowerów i motocykli oraz taboru kolejowego. W regionie tym pomimo spadku produkcji w sektorze motoryzacyjnym (o ok. 30\%, przy 10\% dla Francji) sektor ten nadal posiada $20 \%$ regionalnej wartości dodanej w przemyśle i pozostaje drugim 
jego najważniejszym przemysłem. Również działania państwa na rzecz rozwoju przemysłu zaawansowanych technologii i lokalizacja klastrów innowacyjnych przyczyniają się do wzrostu potencjału gospodarczego Franche-Comté (Dorocki, Brzegowy, 2013b).

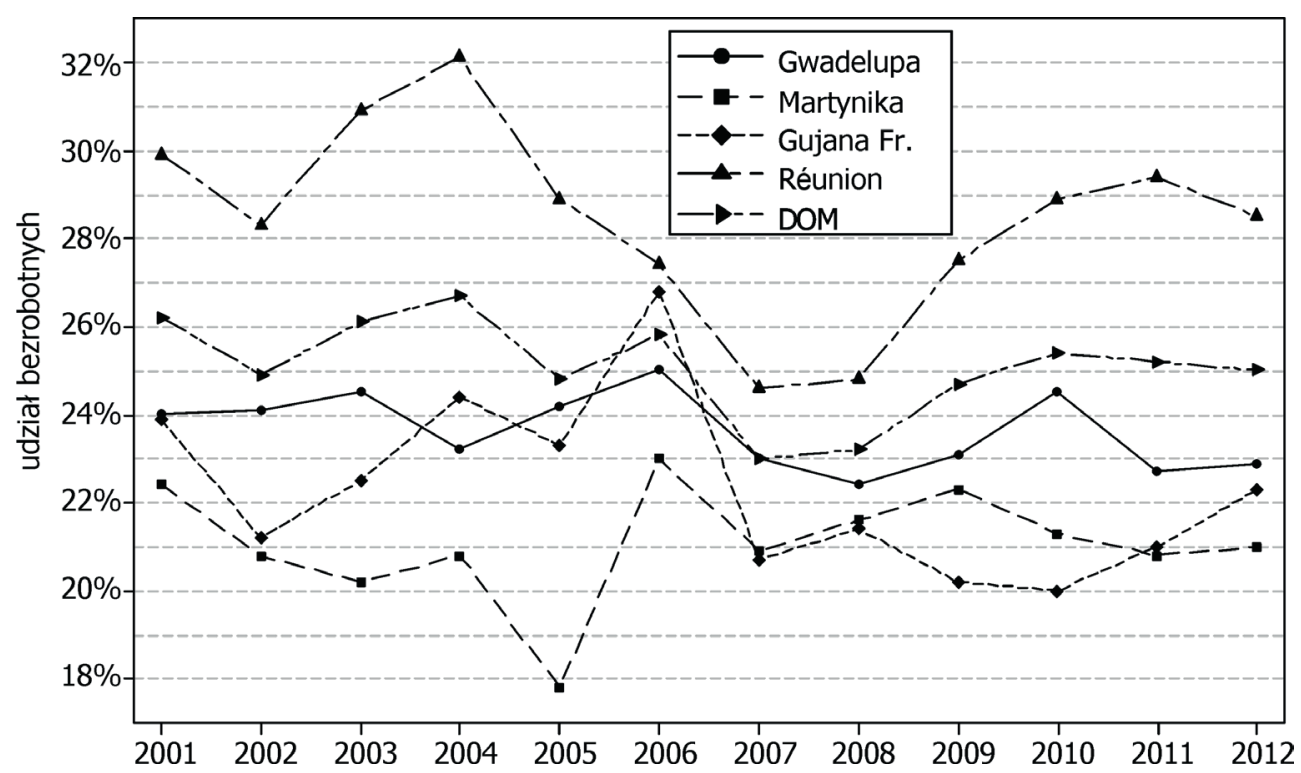

Ryc. 2. Udział bezrobotnych w departamentach Francji zamorskiej w latach 2001-2012

Źródło: opracowanie własne na podstawie danych INSEE

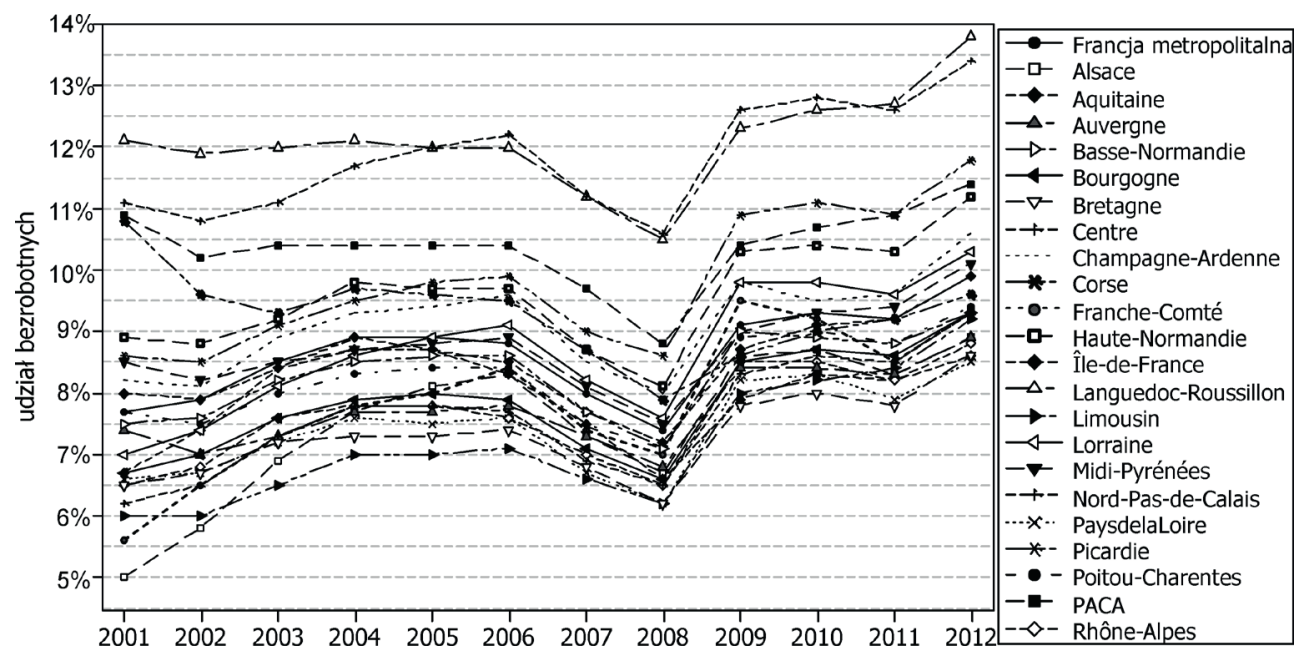

Ryc. 3. Udział bezrobotnych w regionach Francji w latach 2001-2012

Źródło: opracowanie własne na podstawie danych INSEE 


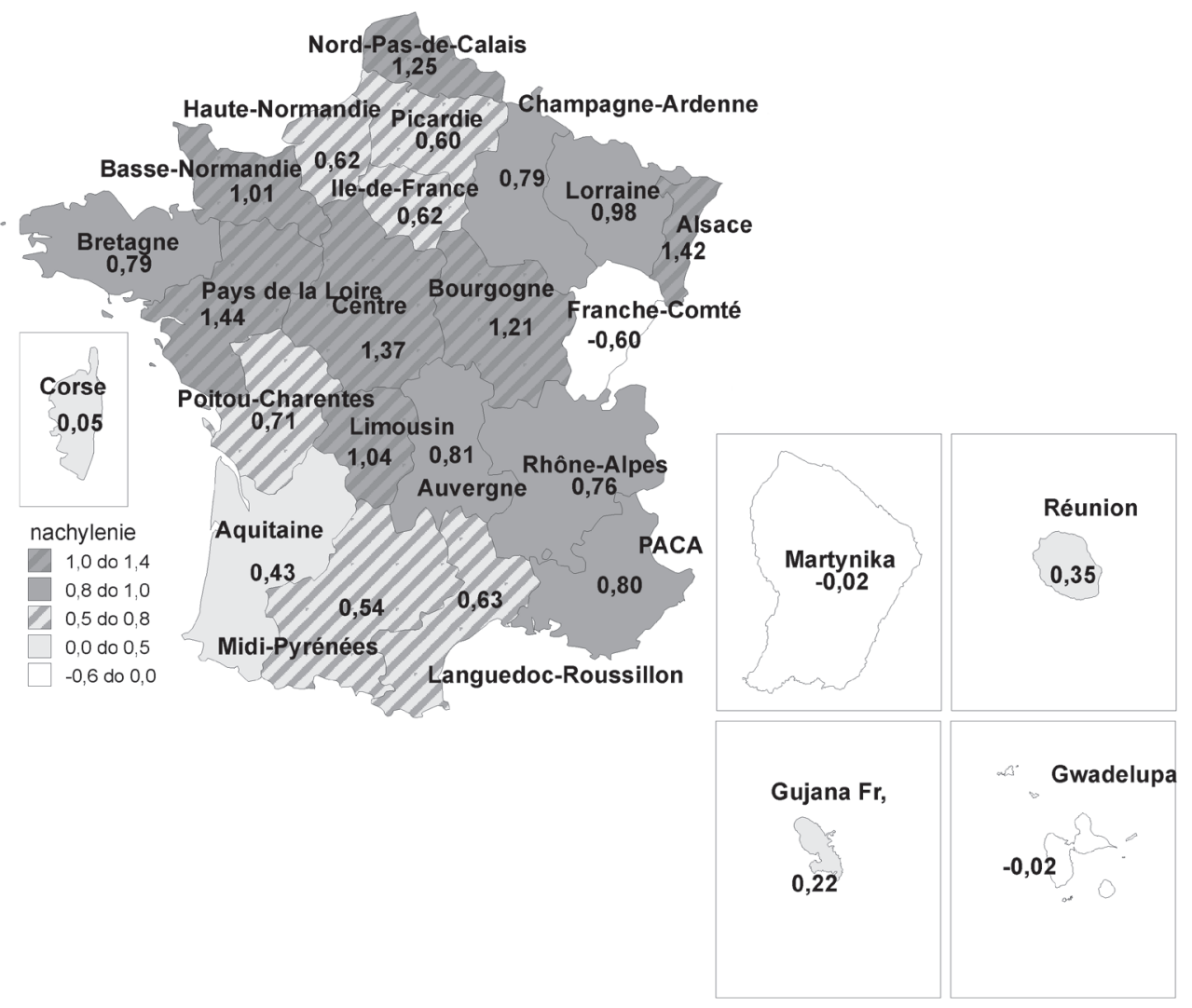

Ryc. 4. Tendencja zmiany udziału bezrobotnych w regionach Francji w latach 2001-2012 według wartości nachylenia

Źródło: opracowanie własne na podstawie danych INSEE

Analizując tendencje zmian udziału bezrobotnych w okresie 2001-2012, można zauważyć, że trend spadkowy bezrobocia wykazywały głównie regiony rozwijające się, tj. - poza wspomnianym Franche-Comté - regiony zamorskie: Martynika i Gwadelupa. Niski wzrost bezrobocia, poniżej wartości 0,5, charakteryzował pozostałe DROM: Gujanę Francuską i Réunion oraz Korsykę i Akwitanię. Ogólnie można przyjąć, że niższy wzrost bezrobocia w wyniku kryzysu odnotowały regiony zamorskie Francji, regiony południowo-zachodnie (od Poitou-Charentes po Langwedocję-Roussillon) i obszar metropolii Paryża, będącej jednym z najbardziej zglobalizowanych miast na świecie (Raźniak, 2013; Raźniak, Winiarczyk-Raźniak, 2013), obejmującej regiony Île-de-France oraz Pikardię i Górną Normandię. Są to regiony o dużym potencjale rozwojowym, skojarzonym z rosnącym wciąż popytem konsumpcyjnym (w tym z usługami związanymi z przemysłem turystycznym) oraz dynamicznie rozwijającą się gospodarką, opartą głównie na rozwoju usług lub sektora wysokich technologii (Dorocki, 2011). 
Innym wskaźnikiem obrazującym zmiany na rynku pracy jest liczba osób aktywnie poszukujących zatrudnienia. Nie odnosi się ona jedynie do osób pozostających bez pracy, lecz obejmuje również tych, którzy chcą zmienić obecną posadę. Także w tym ujęciu niemal we wszystkich departamentach zamorskich Francji można zauważyć po 2008 r. wzrost liczby osób aktywnie poszukujących pracy (ryc. 5). Nieco inaczej przedstawiała się sytuacja w przypadku Gujany Francuskiej. W regionie tym nie odnotowano wcześniejszych tendencji spadkowych, jedynie stagnację w liczbie osób poszukujących pracy. Powodowane jest to bardzo dużym przyrostem naturalnym i wchodzeniem młodego pokolenia na rynek pracy. Drugą przyczyną są działania na rzecz lokalnego rozwoju gospodarczego, w tym projekt „Guyane base avancée", który wiąże się z funkcjonowaniem międzynarodowej stacji kosmicznej.

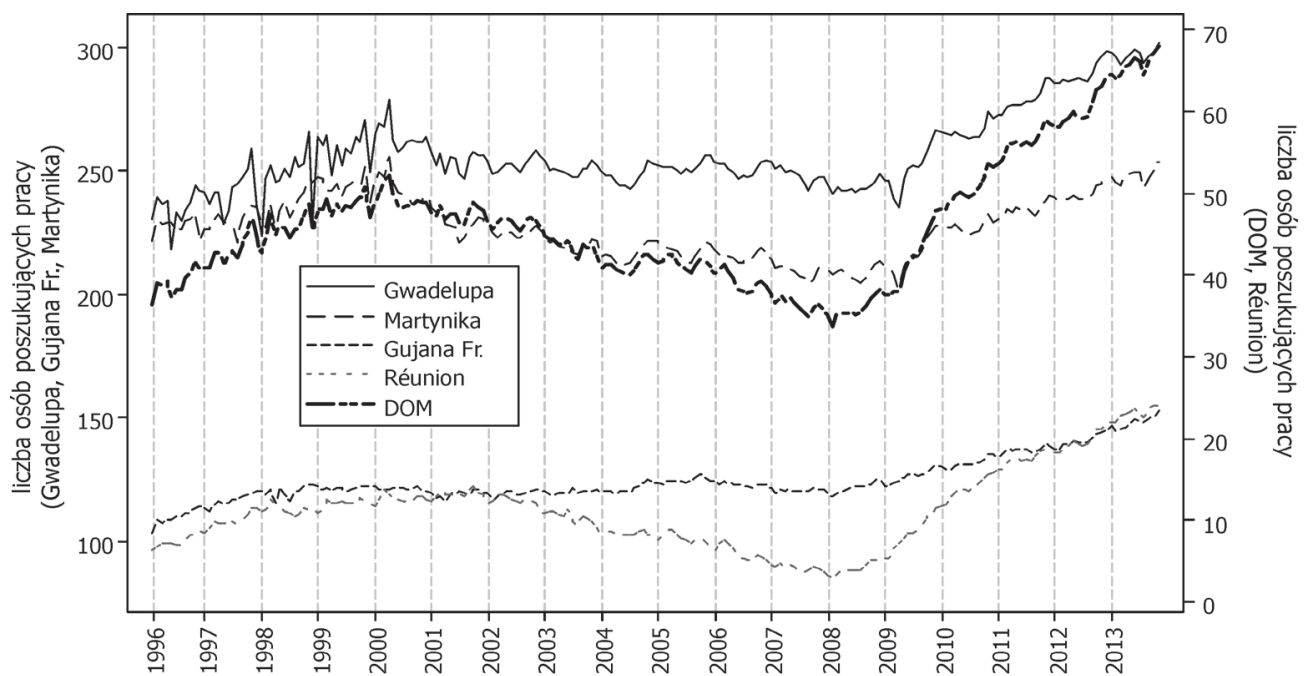

Ryc. 5. Liczba osób poszukujących pracy w departamentach zamorskich Francji w okresie od grudnia 1995 do września 2013

Źródło: opracowanie własne na podstawie danych DGCIS

Również w przypadku regionów europejskich Francji można odnotować wyraźny wzrost liczby osób poszukujących pracy, który trwa nieprzerwanie od połowy 2008 r. (ryc. 6). Należy zatem uznać, że jest on wynikiem globalnego kryzysu gospodarczego. W tym aspekcie zwraca się głównie uwagę na ludzi młodych podejmujących pierwszą pracę. We Francji kontynentalnej ok. 61\% absolwentów z 2012 r. pozostawało bez zatrudnienia w 2013 r. (Lagoutte, 2013). Jeszcze większe trudności w znalezieniu pierwszej pracy mieli ludzie młodzi w DROM, będący zazwyczaj pracownikami o bardzo niskich kwalifikacjach (Dorocki, Brzegowy, 2012). Problem wysokiego bezrobocia wśród ludzi młodych w okresie kryzysu gospodarczego dotyczy także innych krajów europejskich, takich jak Grecja i Hiszpania (Kilar i in., 2013). 

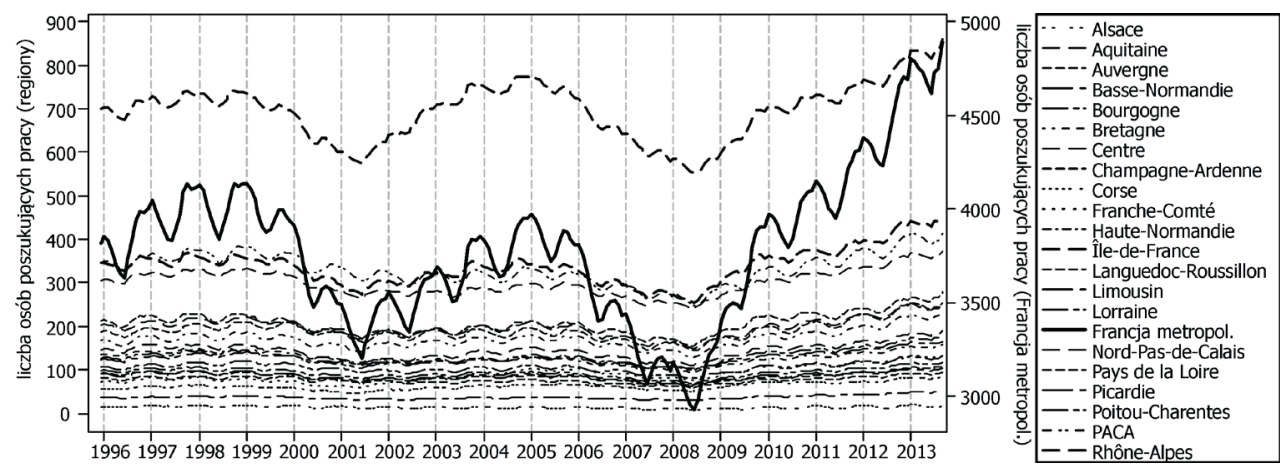

Ryc. 6. Liczba osób poszukujących pracy w regionach Francji metropolitalnej w okresie od grudnia 1995 do września 2013

Źródło: opracowanie własne na podstawie danych DGCIS

Liczba osób poszukujących pracy świadczy o potencjale rynku pracy danego regionu, natomiast natężenie zjawiska w danej społeczności można obserwować poprzez zestawienie osób aktywnie poszukujących pracy z ogólną liczbą osób w wieku produkcyjnym. W warunkach francuskich wiek emerytalny wg najnowszych założeń polityki socjalnej to 67 lat. Zgodnie z przyjętym wskaźnikiem można zaobserwować wyraźny wzrost liczby osób zabiegających o pracę po 2008 r., co wraz z odwróceniem wcześniejszej tendencji spadkowej w liczbie osób poszukujących zatrudnienia świadczy o wpływie globalnego kryzysu na niestabilność rynku pracy w DROM (ryc. 7). Spośród departamentów zamorskich największy wzrost liczby osób poszukujących pracy w przeliczeniu na ogólną liczbę mieszkańców w porównaniu do okresu sprzed kryzysu odnotowano w Réunion i Gwadelupie. Tam niekorzystna sytuacja na rynku pracy doprowadziła do konieczności podjęcia działań przez władze w Paryżu w celu odwrócenia niekorzystnej tendencji na rynku pracy (Ledain, 2013).

Również na kontynencie nastąpiło odwrócenie trendu na rynku pracy i wzrost liczby osób poszukując zatrudnienia w przeliczeniu na 10 tys. osób w wieku 15-67 lat po roku 2008 (ryc. 8). Spośród regionów europejskich Francji największy wzrost wystąpił w jednym z najbardziej rozwiniętych jej regionów - Alzacji, podczas gdy najmniejszy odnotowała Korsyka, pomimo wyraźnego wpływu kryzysu na sferę usług turystycznych (Tempier, 2013). Tak wysoki przyrost liczby osób poszukujących pracy w ogóle ludności Alzacji, która do 2003 r. odznaczała się najniższymi wartościami, tłumaczy się dużym udziałem zatrudnienia w przemyśle, który gorzej niż sektor usługowy zareagował na kryzys (Lacroix, 2012). Spadek zatrudnienia nastąpił we wszystkich sektorach przemysłu. Największe zwolnienia od 2008 r. odnotowano w sektorach: produkcja sprzętu elektrycznego, elektronicznego, komputerowego, produkcja maszyn; produkcja sprzętu transportowego, w tym przemysł motoryzacyjny oraz produkcja pozostałych wyrobów przemysłowych. Dodatkowym czynnikiem wpływającym na wzrost bezrobocia w regionach przygranicznych Francji jest urata pracy przez mieszkańców regionów pracujących za granicą - w Niemczech i Szwajcarii (Labosse, 2010). 


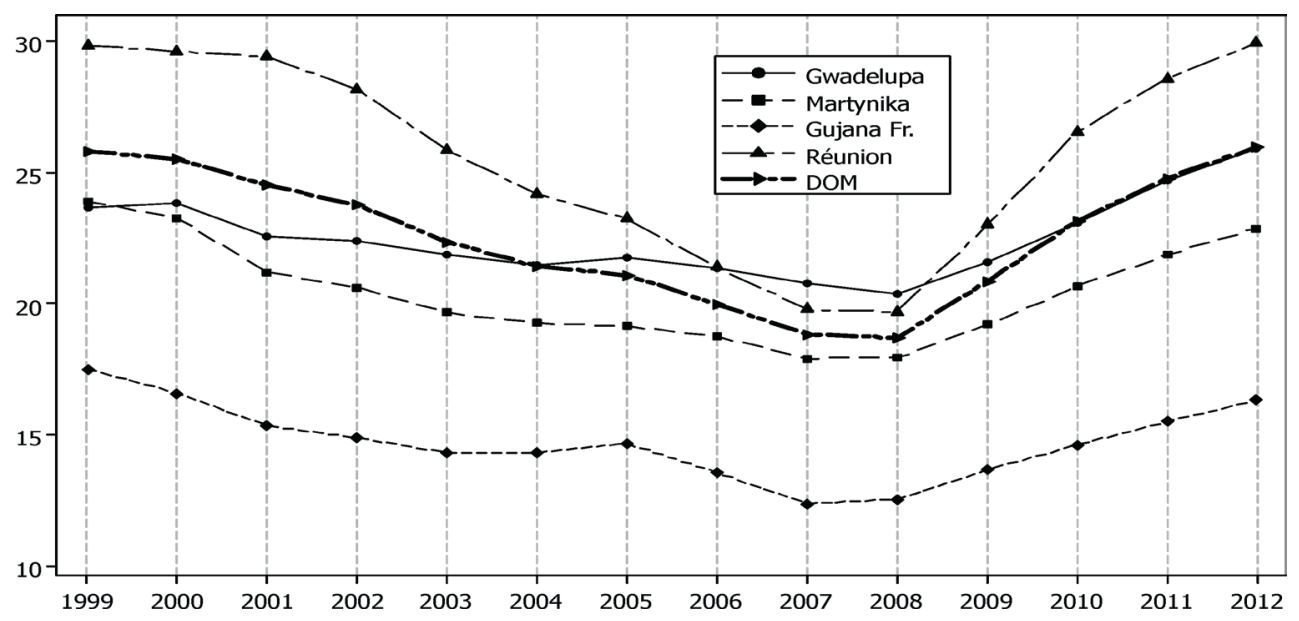

Ryc. 7. Liczba osób poszukujących pracy na 10 tys. mieszkańców w wieku 15-67 lat w departamentach zamorskich Francji w latach 1999-2012

Źródło: opracowanie własne na podstawie danych DGCIS

W celu zobrazowania sytuacji ekonomicznej regionów dokonano wyliczenia zmodyfikowanego rzeczywistego wskaźnika obciążenia ekonomicznego. Dokonawszy jego oszacowania, nie odniesiono się jedynie do zestawienia liczby osób w wieku nieprodukcyjnym na 100 osób w wieku produkcyjnym, ale wykorzystano ogólną liczbę osób niepracujących (w tym bezrobotnych oraz osób w wieku przed- i poprodukcyjnym), uwzględniając ponadto liczbę osób faktycznie pracujących i płacących podatki oraz utrzymujących osoby pozostające we wspólnym gospodarstwie domowym.

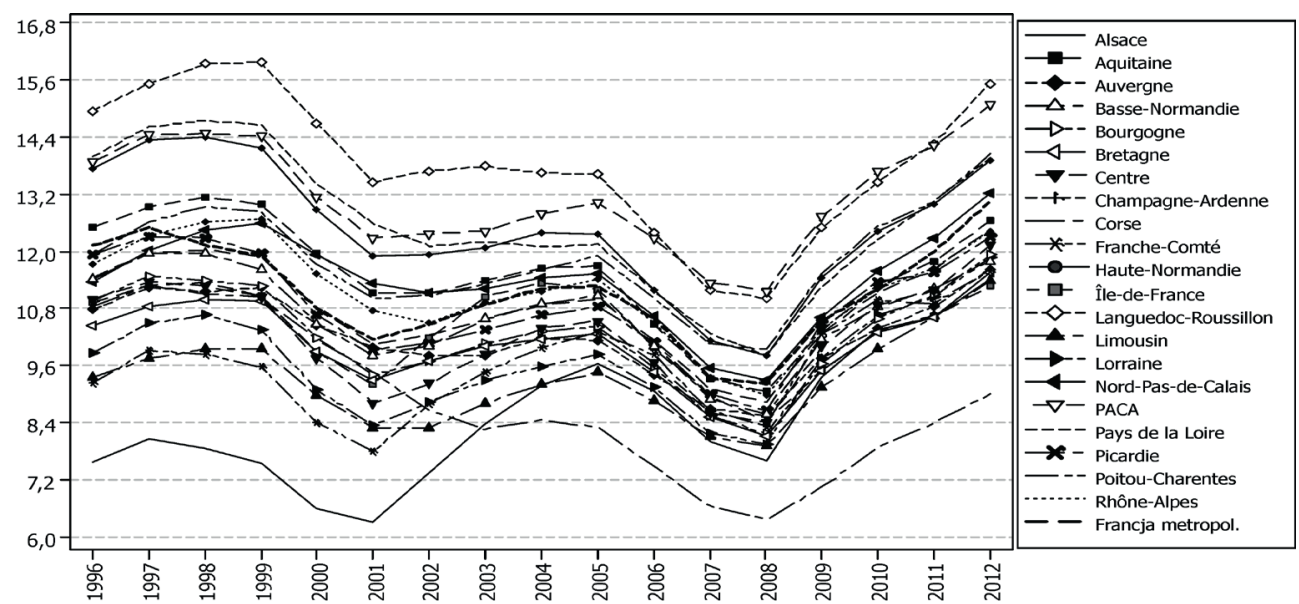

Ryc. 8. Liczba osób poszukujących pracy na 10 tys. mieszkańców w wieku od 15-67 lat w regionach Francji metropolitalnej w latach 1996-2012

Źródło: opracowanie własne na podstawie danych DGCIS 
Największym obciążeniem ekonomicznym spośród departamentów zamorskich Francji oznaczał się najbiedniejszy departament - Gujana Francuska. Od roku 2001 liczba osób niepracujących na 100 pracujących wzrosła z ok. 290 do 360 osób (ryc. 9). W pozostałych departamentach w okresie kryzysu nastąpił niewielki wzrost liczby osób niepracujących w stosunku do pracujących. Jedynie w Gwadelupie można obserwować ciągły spadek liczby osób niepracujących. W regionach metropolitalnych udział osób pozostających na utrzymaniu osób pracujących jest mniejszy o ok. 100 osób niż w DROM. Jednakże w większości regionów nastąpił utrzymujący się do 2011 r. wzrost liczby osób niepracujących (ryc. 10). Jedynie w przypadku Korsyki, którą w 2001 r. cechował największy wśród regionów Francji współczynnik osób niepracujących, można zauważyć wyraźną tendencję spadkową. W przypadku departamentów zamorskich obciążenie związane jest zarówno z wysokim bezrobociem, jak i znacznym przyrostem naturalnym, co wpływa na wzrost liczby osób w wieku przedprodukcyjnym. Tymczasem na kontynencie obciążenie ekonomiczne osób pracujących powodowane jest, poza bezrobociem, przede wszystkim procesem starzenia się społeczeństwa.

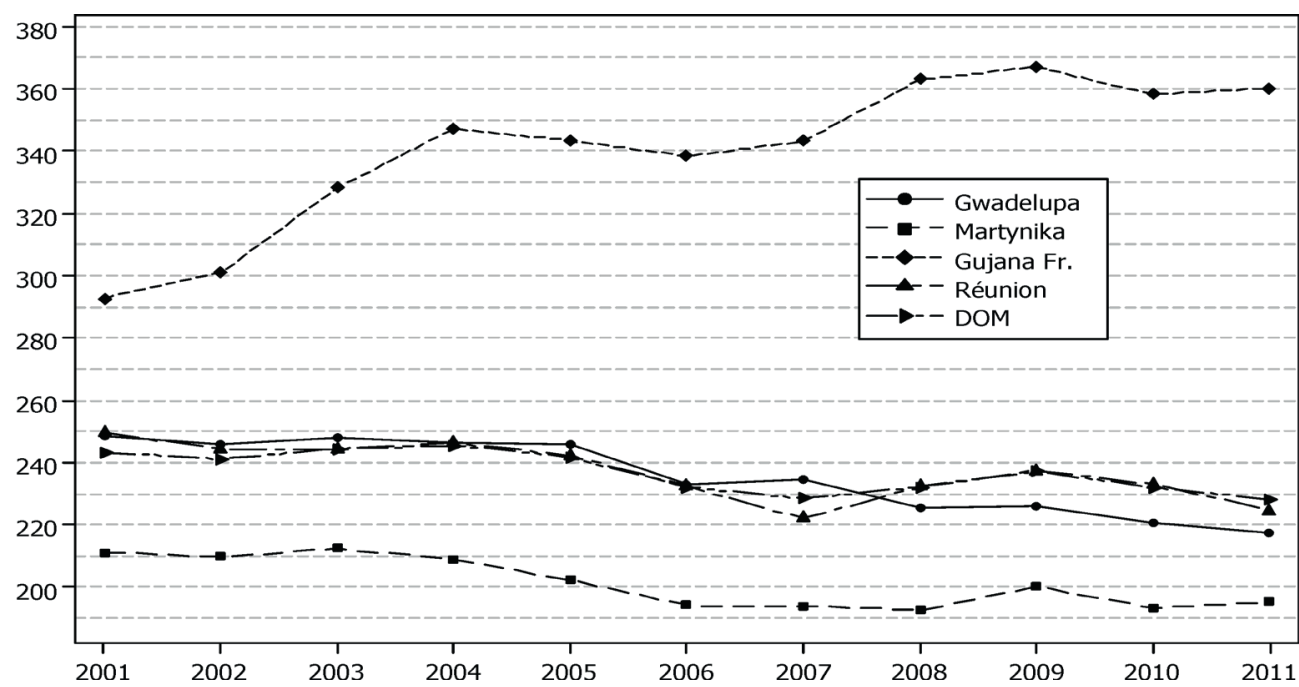

Ryc. 9. Liczba osób niepracujących w ogóle ludności regionu na 100 osób pracujących w departamentach zamorskich Francji w latach 2001-2011

Źródło: opracowanie własne na podstawie danych DGCIS

Innym wskaźnikiem wpływu kryzysu na sytuację gospodarczą jest liczba zlikwidowanych i upadłych podmiotów gospodarczych (Bauer, 2010; Tokarski, 2010). W przypadku DOM, jak i Francji metropolitalnej, można zauważyć, że w latach 2007-2009 nastąpił wyraźny wzrost liczby zlikwidowanych i upadłych firm (ryc. 11). Jednak w odniesieniu do Gwadelupy i Gujany Francuskiej oddziaływanie kryzysu nie jest tak wyraźne jak w pozostałych dwóch departamentach zamorskich Francji. Natomiast w przypadku Francji metropolitalnej wpływ kryzysu na liczbę bankructw przedsiębiorstw zaznaczył się w większości regionów i był ograniczony do okresu 2008-2010 (ryc. 12). Jednakże w sytuacji licznych 
regionów kontynentalnych liczba bankructw nie przekroczyła lub nawiązywała do poziomu upadłości z lat 1995-1998. Spośród wszystkich regionów Francji największą liczbę upadłości odnotowano w rozwiniętym regionie Rodan-Alpy, gdzie na ich dużą liczbę (20\% upadłości Francji w 2009 r.) wpłynęły bankructwa firm z branży B2C oraz B2B, w tym przedsiębiorstw zarówno z sektora MŚP, jak i dużych międzynarodowych koncernów.

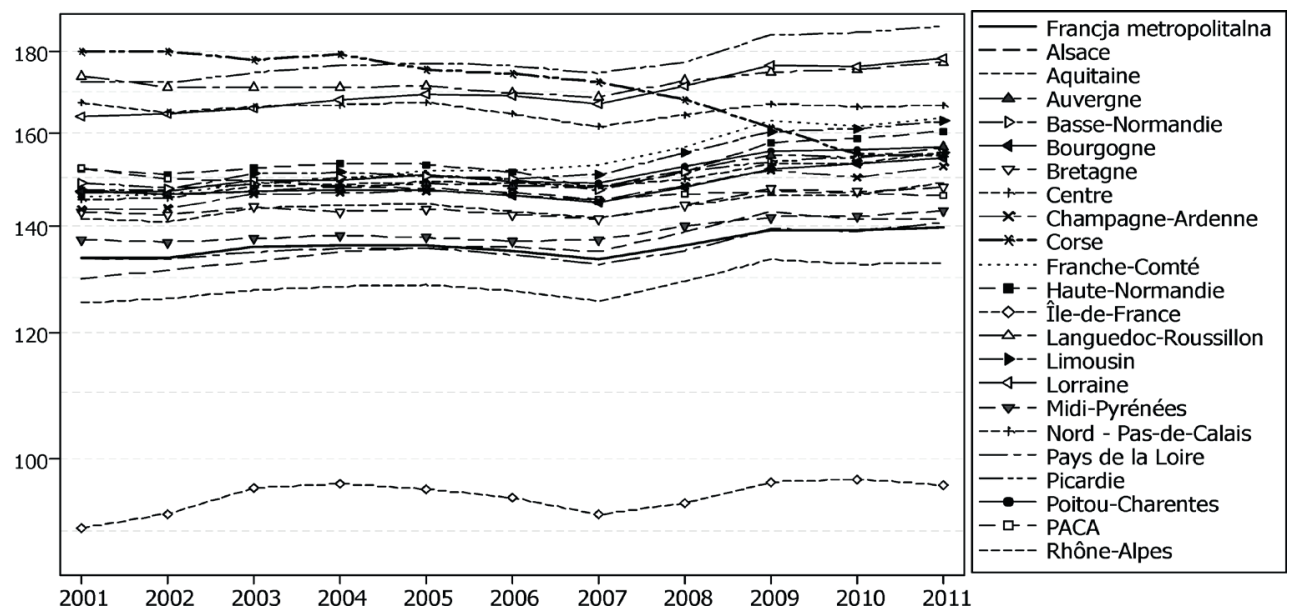

Ryc. 10. Liczba osób niepracujących w ogóle ludności regionu na 100 osób pracujących w regionach Francji metropolitalnej w latach 2001-2011

Źródło: opracowanie własne na podstawie danych DGCIS

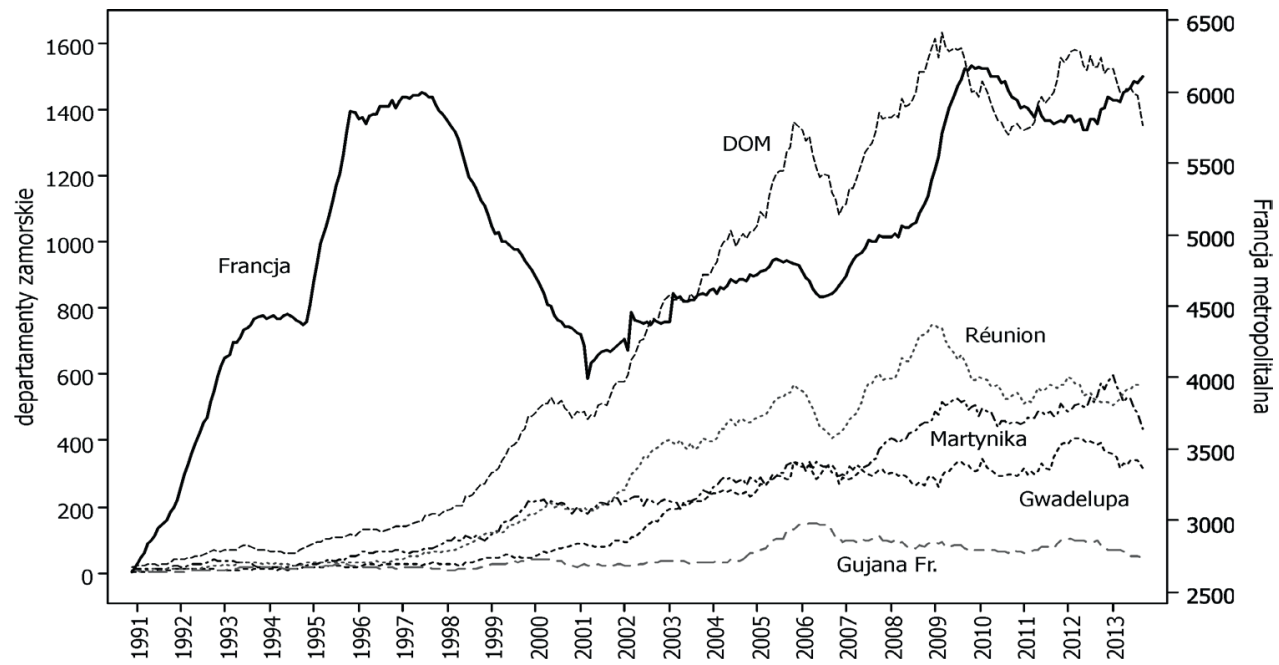

Ryc. 11. Liczba zlikwidowanych i upadłych firm w departamentach Francji zamorskiej na tle Francji metropolitalnej w okresie od grudnia 1990 do września 2013

Źródło: opracowanie własne na podstawie danych DGCIS 


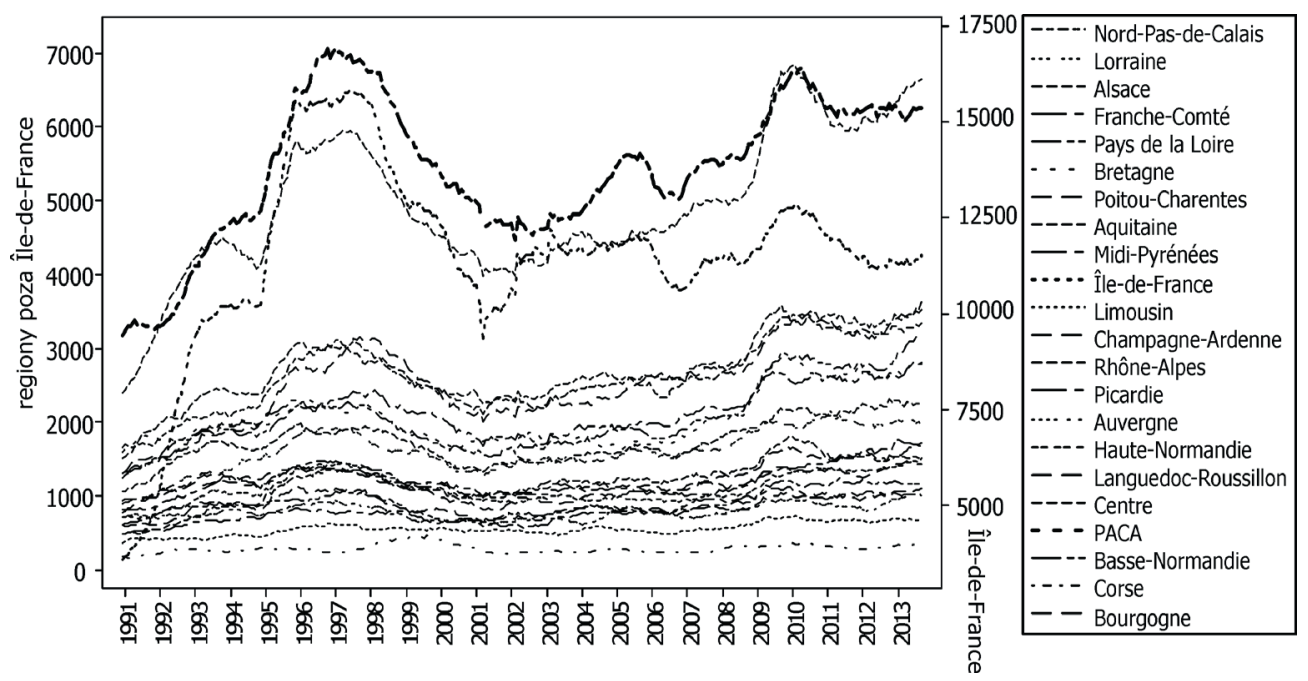

Ryc. 12. Liczba zlikwidowanych firm w regionach Francji metropolitalnej w okresie od grudnia 1990 do września 2013

Źródło: opracowanie własne na podstawie danych DGCIS

Analizując strukturę likwidowanych i upadłych przedsiębiorstw we Francji zamorskiej, należy odnotować, iż w latach kryzysu na upadek narażone były w pierwszej kolejności małe i średnie firmy z sektora handlu oraz budownictwa. Upadek firm z sektora MŚP według analityków był konsekwencją złego stanu tych podmiotów w okresie poprzedzającym kryzys oraz małych zasobów finansowych lub kapitałowych, pozwalających na przetrwanie trudniejszych okresów gospodarczych w porównaniu z dużymi firmami (Schaeffer, 2012). Natomiast w Europie wśród upadających firm przeważały przedsiębiorstwa z branży turystycznej (hotelarstwo i wyżywienie) oraz, podobnie jak w DROM, prowadzące działalność w handlu i usługach.

Przyglądając się natomiast strukturze i liczbie nowo powstałych firm w departamentach zamorskich, można zauważyć po pierwsze wzrost liczby nowych podmiotów gospodarczych w okresie kryzysu, co związane było ze zmianami legislacyjnymi dotyczącymi zakładania przedsiębiorstw jednoosobowych. We wszystkich departamentach w okresie kryzysu nastąpił wzrost liczby firm z sektora usług, co jest konsekwencją trendu obserwowanego od początku XXI w. W mniejszym stopniu wzrosła liczba przedsiębiorstw z sektora handlu, transportu oraz zakwaterowania i wyżywienia, co jest współzależne z rozwojem funkcji turystycznych na obszarze departamentów zamorskich (Dorocki, Brzegowy, 2013a). Tymczasem w przypadku firm budowlanych i przemysłowych nie nastąpiła wyraźna zmiana ich liczby. Wyjątkiem był Réunion, gdzie odnotowano w okresie kryzysu wzrost nowo powstałych zakładów przemysłowych. Wynikało to z rozwoju przemysłu spożywczego (destylarni rumu i olejków zapachowych, cukrowni) oraz przemysłu materiałów budowlanych. 


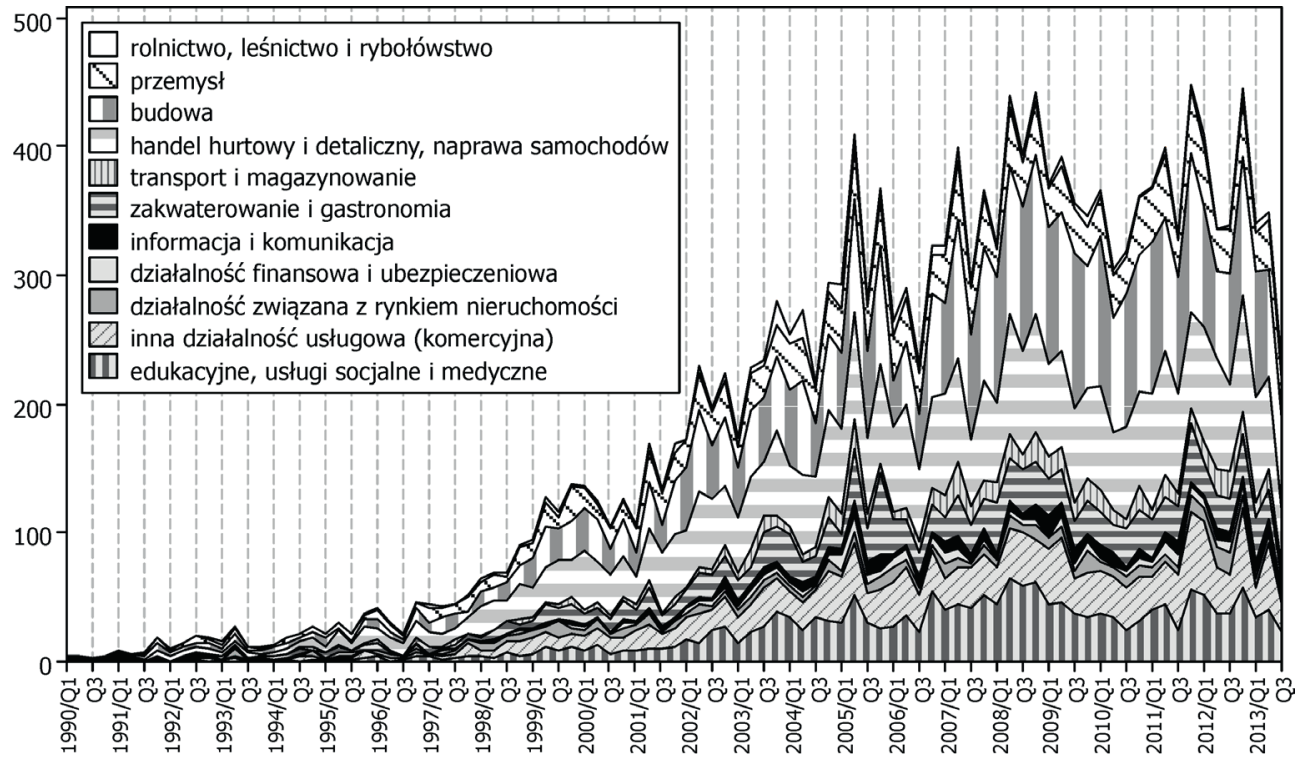

Ryc. 13. Liczba zlikwidowanych firm w regionach Francji metropolitalnej w okresie od grudnia 1990 do września 2013

Źródło: opracowanie własne na podstawie danych DGCIS
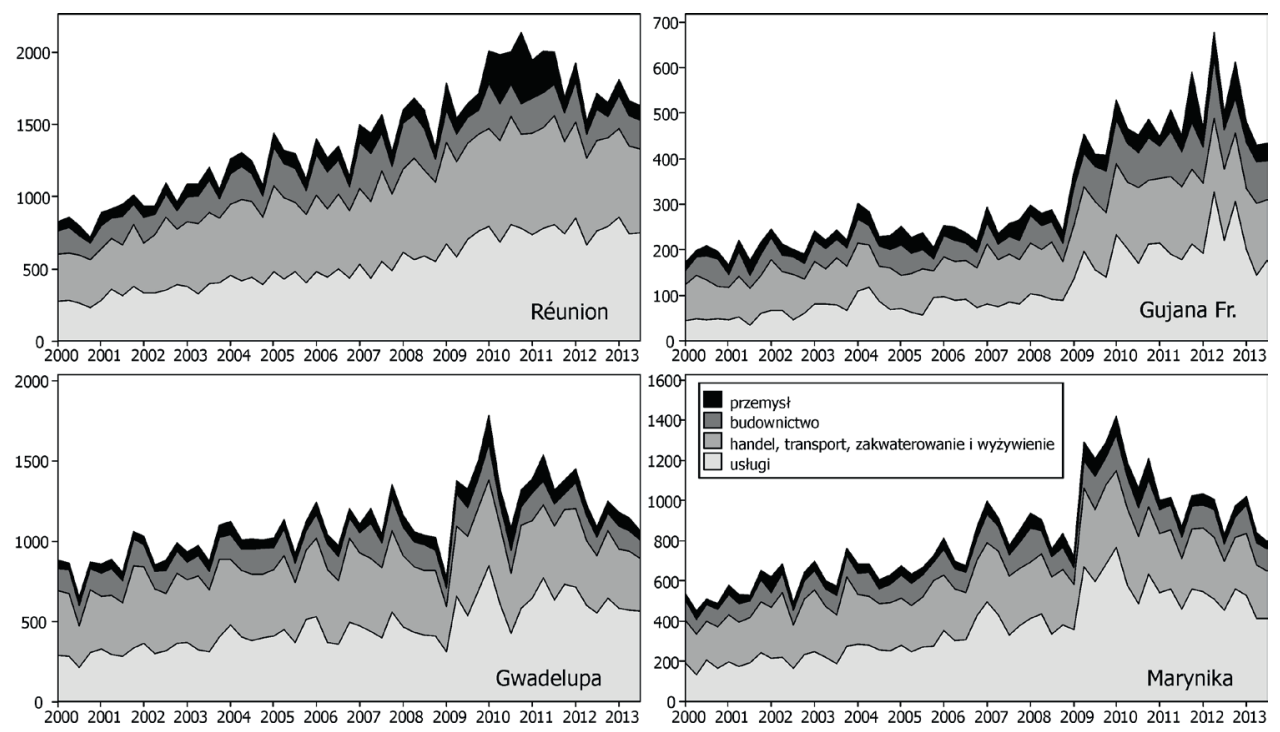

Ryc. 14. Struktura nowo powstałych firm we Francji zamorskiej w okresie od I kw. 2000 do II kw. 2013 r.

Źródło: opracowanie własne na podstawie danych DGCIS 
Porównując liczbę bankructw przedsiębiorstw na 100 nowo powstałych firm w departamentach zamorskich Francji, można zauważyć, że od 2000 r. następował powolny wzrost upadłości, który w 2005 r. osiągnął wartość maksymalną. Następna zwyżka wartości bankructw miała miejsce w okresie 2008-2009, co wiązało się z kryzysem światowym. Po okresie spadku zaistniało spotęgowanie niepowodzeń gospodarczych w 2013 r. Związane to było ze stratami licznych firm powstałych na fali przemian legislacyjnych, ułatwiających samozatrudnienie. Spośród analizowanych departamentów najsłabsze wyniki odnotowała Martynika, w przypadku której nie nastąpił spadek wartości bankructw, lecz obserwowano ciągły ich wzrost w stosunku do liczby nowych podmiotów gospodarczych (ok. 150 upadłości na 100 nowo powstałych; ryc. 15). Natomiast w Gujanie Francuskiej po okresie kryzysu zauważalna była tendencja spadkowa liczby upadłości do ok. 30 na 100 nowo utworzonych podmiotów gospodarczych w $2013 \mathrm{r}$.

W przypadku Francji kontynentalnej liczba niepowodzeń gospodarczych w stosunku do nowo powstałych firm pozostawała zdecydowanie niższa niż w przypadku DROM. W analizowanym okresie, pomimo gwałtownego wzrostu upadłości w czasie kryzysu, który odczuły wszystkie regiony, obserwowano spadek upadłości z ok. 20 na początku XXI w. do 10 w 2013 r. na 100 nowo powstałych. Wartości te w poszczególnych regionach są do siebie zbliżone i wykazują od 2011 r. niewielką tendencję wzrostową (ryc. 16). Świadczy to o większej stabilności gospodarki kontynentalnej w stosunku do obszarów zamorskich oraz o wzrastającym doświadczeniu kontynentalnych przedsiębiorców, co związane może być również z ich przygotowaniem edukacyjnym (Dorocki, Brzegowy, 2012).

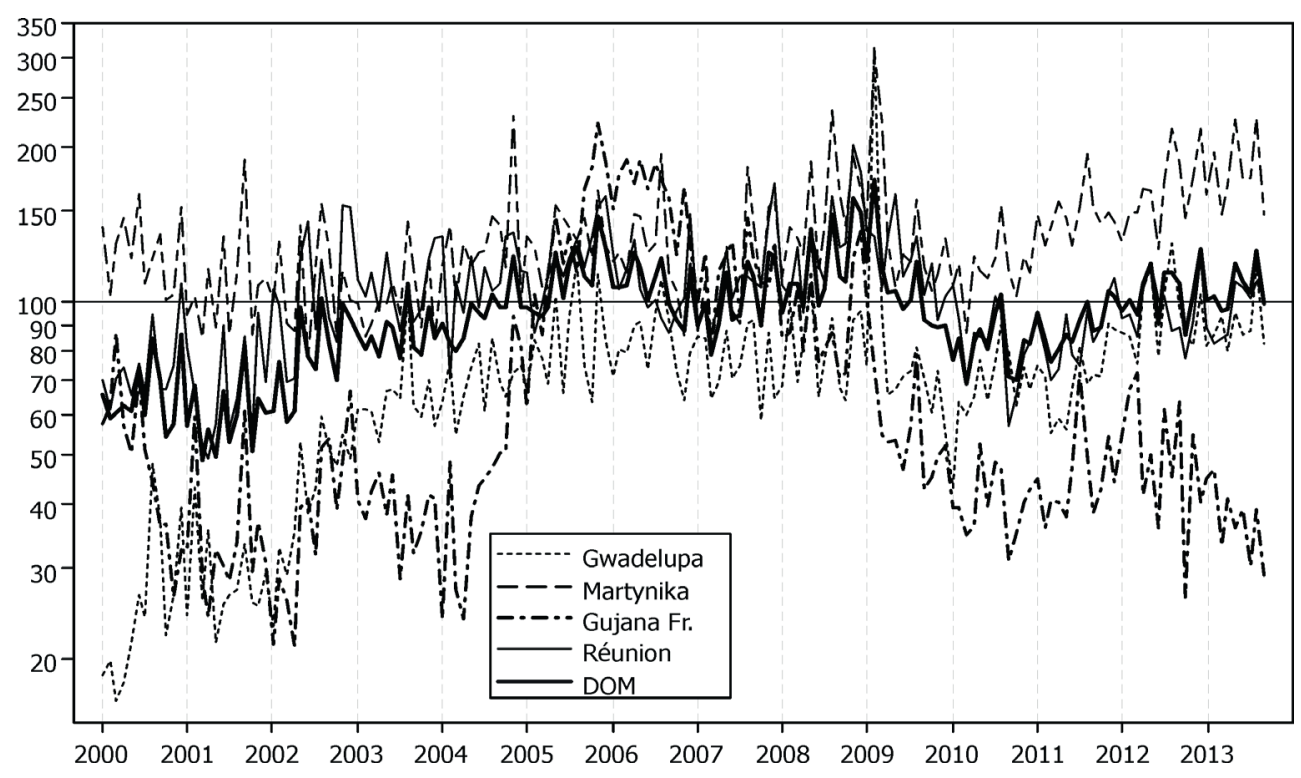

Ryc. 15. Liczba zlikwidowanych firm na 100 nowo powstałych w departamentach zamorskich Francji od stycznia 2000 do września 2013 


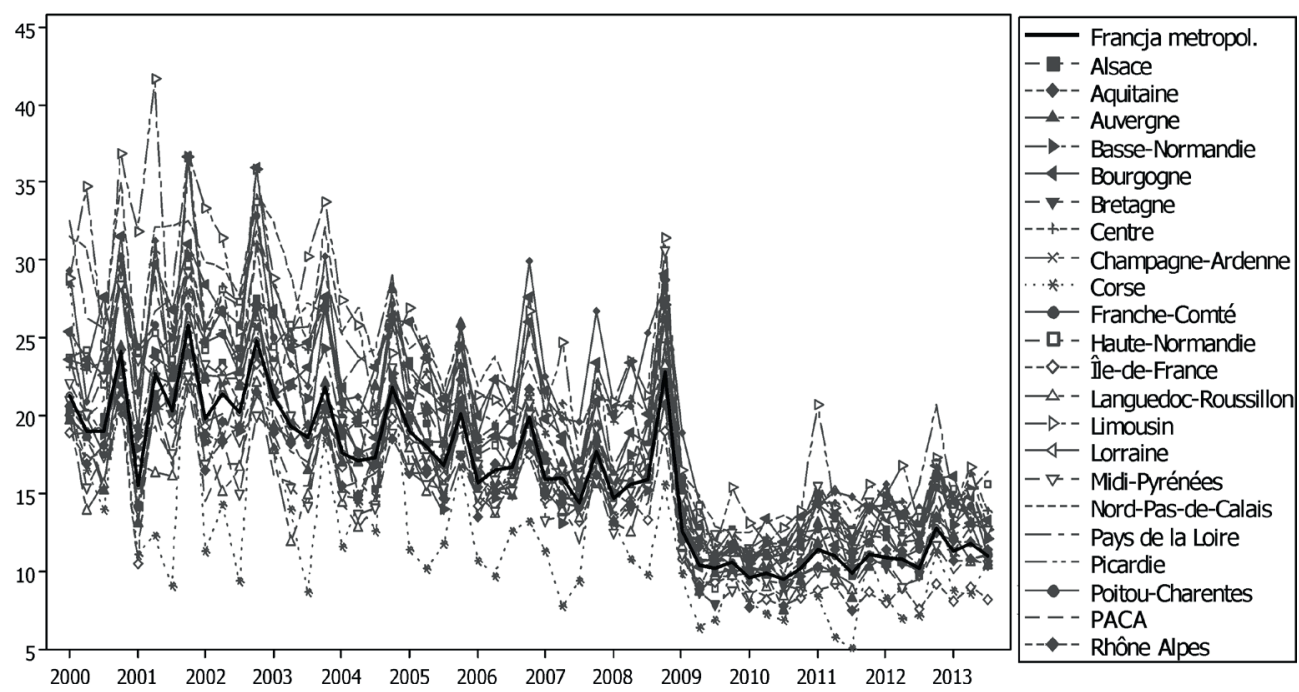

Ryc. 16. Liczba zlikwidowanych firm na 100 nowo powstałych w regionach Francji metropolitalnej w okresie od I kw. 2000 do III kw. 2013

Źródło: opracowanie własne na podstawie danych DGCIS

W wyniku wzrostu liczby bankructw firm oraz wysokiego bezrobocia we Francji podjęto działania mające na celu rozwój samozatrudnienia jako odpowiedzi na wzrost bezrobocia. Podobne działania przedsięwzięto w większości krajów europejskich (Dąbrowski, 2010; Kurek, Rachwał, 2010; Dorocki, Świętek, 2013).

Zarówno w przypadku Francji metropolitalnej, jak i departamentów zamorskich można zauważyć wzrost wielkości samozatrudnienia w okresie kryzysu światowego (ryc. 17A). We Francji zamorskiej dynamika zmian w okresie przed i w czasie kryzysu była wyższa niż na kontynencie (ryc. 17B). Spośród departamentów zamorskich najniższą dynamiką odznaczała się Gujana Francuska, podczas gdy pozostałe departamenty w podobny sposób zareagowały na kryzys w kwestii samozatrudnienia.

Śledząc zmianę liczby osób samozatrudnionych w stosunku do zatrudnionych, można zauważyć, że zarówno w DOM, jak i we Francji metropolitalnej następował od lat 90. XX w. spadek liczby osób w pierwszej ze wskazanych grup. W przypadku DOM wartości te zmalały z 11 osób w 1990 r. do 7 osób samozatrudnionych na 100 na etacie w 2008 r., podczas gdy w regionach kontynentalnych wartości te zmieniły się odpowiednio z 16 do 11 osób. Świadczy to o większej skali przedsiębiorczości na kontynencie. Zaznaczyć należy, że w przypadku regionów metropolitalnych istniało duże zróżnicowanie wartości udziału osób samozatrudnionych. Największą liczbą firm jednoosobowych odznaczały się słabiej rozwinięte peryferyjne regiony Francji: Midi-Pyrénées, Bretania, Langwedocja-Roussillon, Owernia, Korsyka (od 27 osób w 1990 i 17 osób w 2008) (ryc. 19), podczas gdy w rozwiniętych regionach (np. Île-deFrance, Alzacja, Nord-Pas-de-Calais) wartości te wynosiły poniżej 10 osób. 

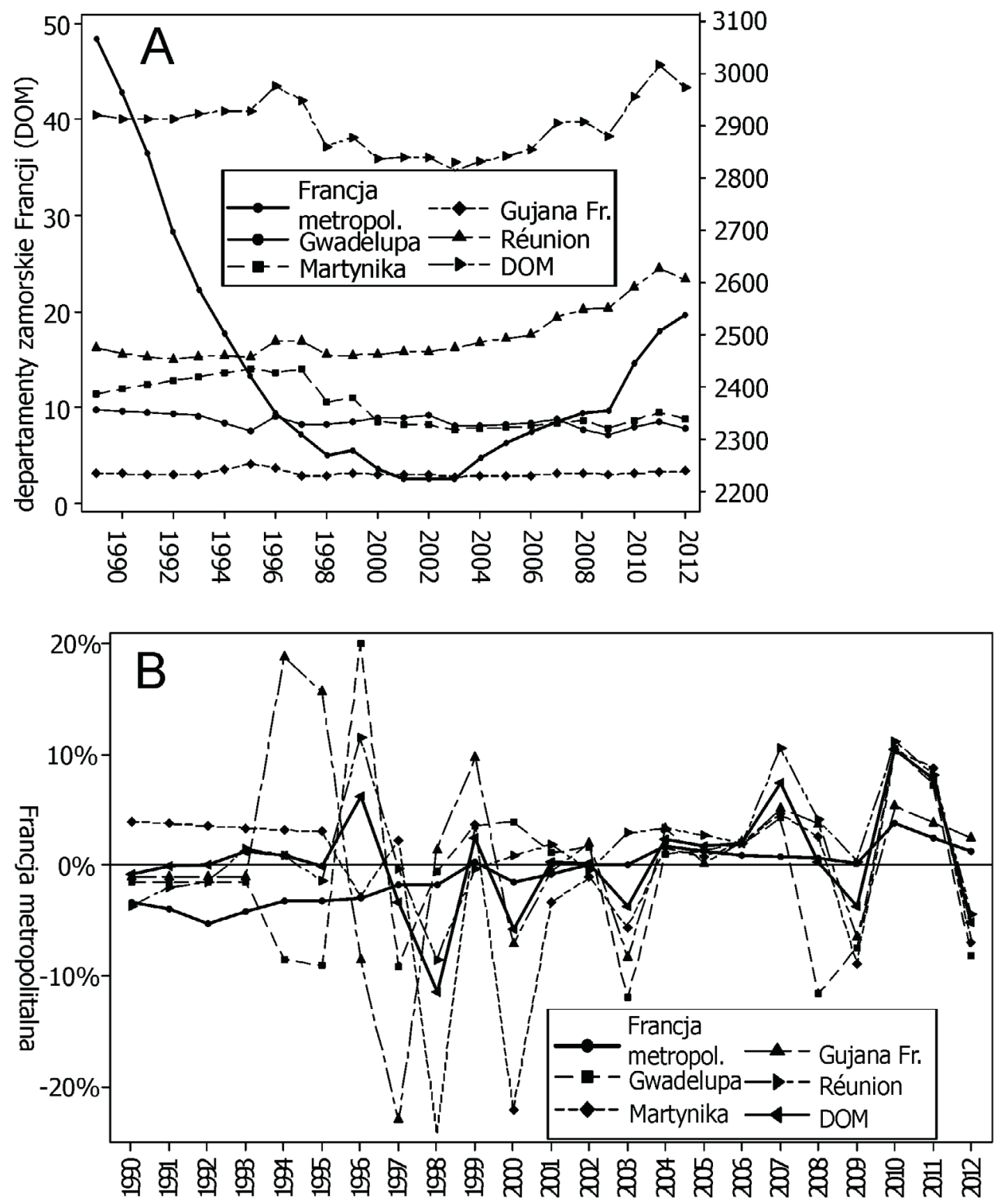

Ryc. 17. Liczba osób samozatrudnionych w regionach Francji zamorskiej w latach 1989-2012 na tle wartości dla Francji metropolitalnej (A) oraz średnioroczna zmiana liczby osób samozatrudnionych w regionach Francji zamorskiej w latach 1989-2012 na tle wartości dla Francji metropolitalnej (B) 


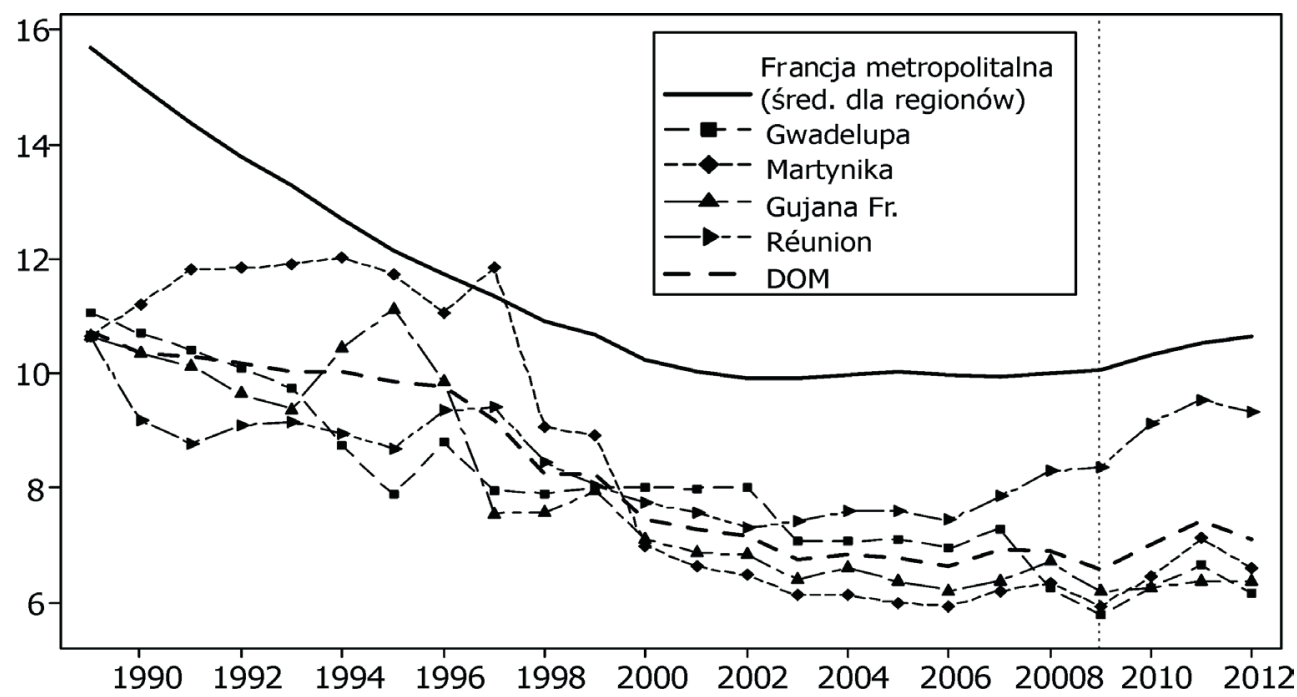

Ryc. 18. Liczba osób samozatrudnionych na 100 zatrudnionych w regionach Francji zamorskiej w latach 1989-2012 na tle wartości średnich dla Francji metropolitalnej

Źródło: opracowanie własne na podstawie danych DGCIS

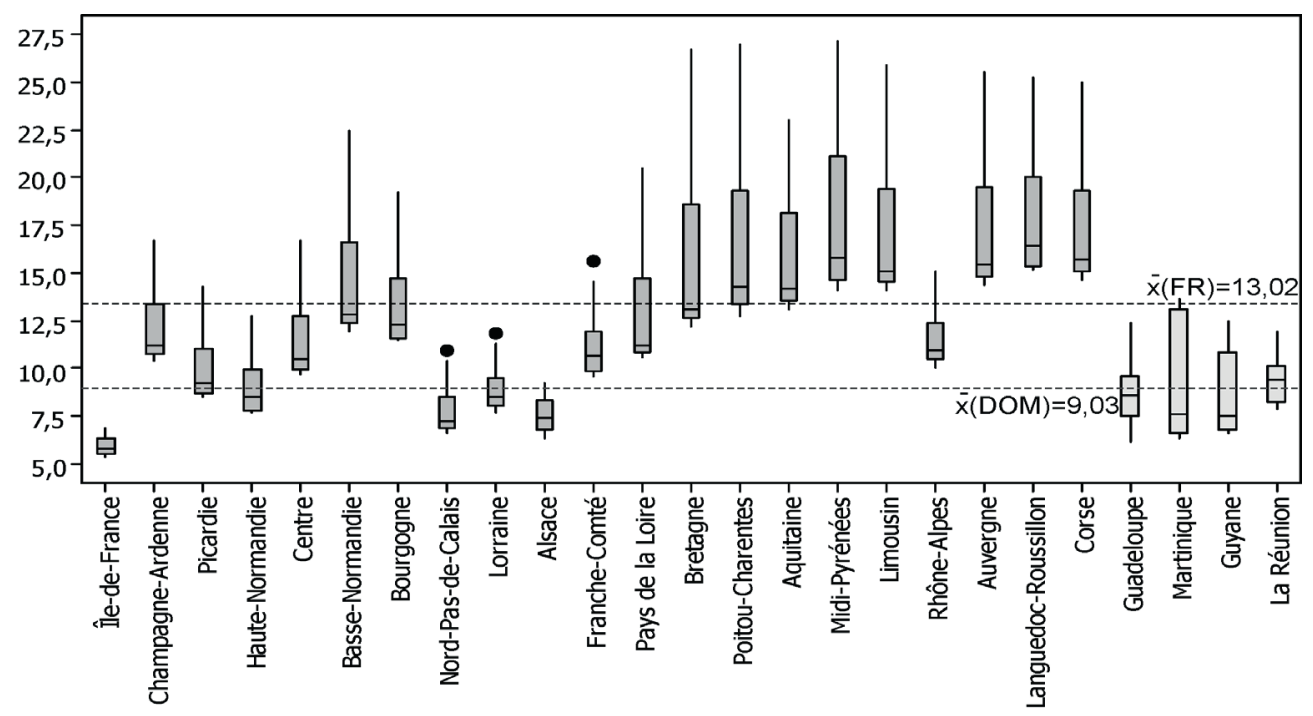

Ryc. 19. Zróżnicowanie liczby osób samozatrudnionych na 100 zatrudnionych w regionach Francji w latach 1989-2012

Źródło: opracowanie własne na podstawie danych DGCIS 
W okresie kryzysu nastąpił wzrost liczby osób samozatrudnionych. Wynikało to ze wspomnianych zmian legislacyjnych zachęcających do samozatrudnienia poprzez ułatwienia administracyjne i zachęty finansowe oraz ze wzrostu bezrobocia i problemów związanych z poszukiwaniem pracy. Największy wzrost samozatrudnienia w okresie kryzysu w stosunku do lat wcześniejszych cechował regiony rozwinięte gospodarczo, które w znaczący sposób odczuły skutki kryzysu (ryc. 20). Były to regiony z dużym udziałem przemysłu w lokalnej gospodarce. Również duży wzrost odnotowały departamenty zamorskie: Réunion i Martynika.

Ostatnim wykorzystanym wskaźnikiem mającym na celu zilustrowanie zmian, które zaszły w gospodarce departamentów Francji w wyniku światowego kryzysu finansowego z 2008 r., jest struktura zatrudnienia. Analiza działów gospodarki pozwala zauważyć, że we wszystkich departamentach zamorskich Francji w wyniku kryzysu nastąpiło załamanie zatrudnienia w budownictwie, które od początku XXI w. było najszybciej rozwijającym się sektorem gospodarki (ryc. 21).

W wyniku spadku zatrudnienia w sektorze budowlanym uwidocznił się wzrost zatrudnienia w rolnictwie, a w przypadku Gujany Francuskiej i Gwadelupy w przemyśle. Oznacza to, że zmiany dotyczyły głównie najmniej licznych sektorów gospodarki DROM (ryc. 22). W stosunku do pozostałych sektorów gospodarki w DROM brak jest ogólnej tendencji i zatrudnienie w poszczególnych departamentach odmiennie zareagowało na kryzys światowy. We Francji metropolitalnej dekoniunktura nie wpłynęła znacząco na tendencje zmian w zatrudnieniu. Wzrost odnotowały sektory handlu i usług, przy kierunku spadkowym w rolnictwie. Natomiast zmiany w wielkości zatrudnienia w przemyśle i budownictwie nie wykazywały związków z kryzysem (ryc. 22).

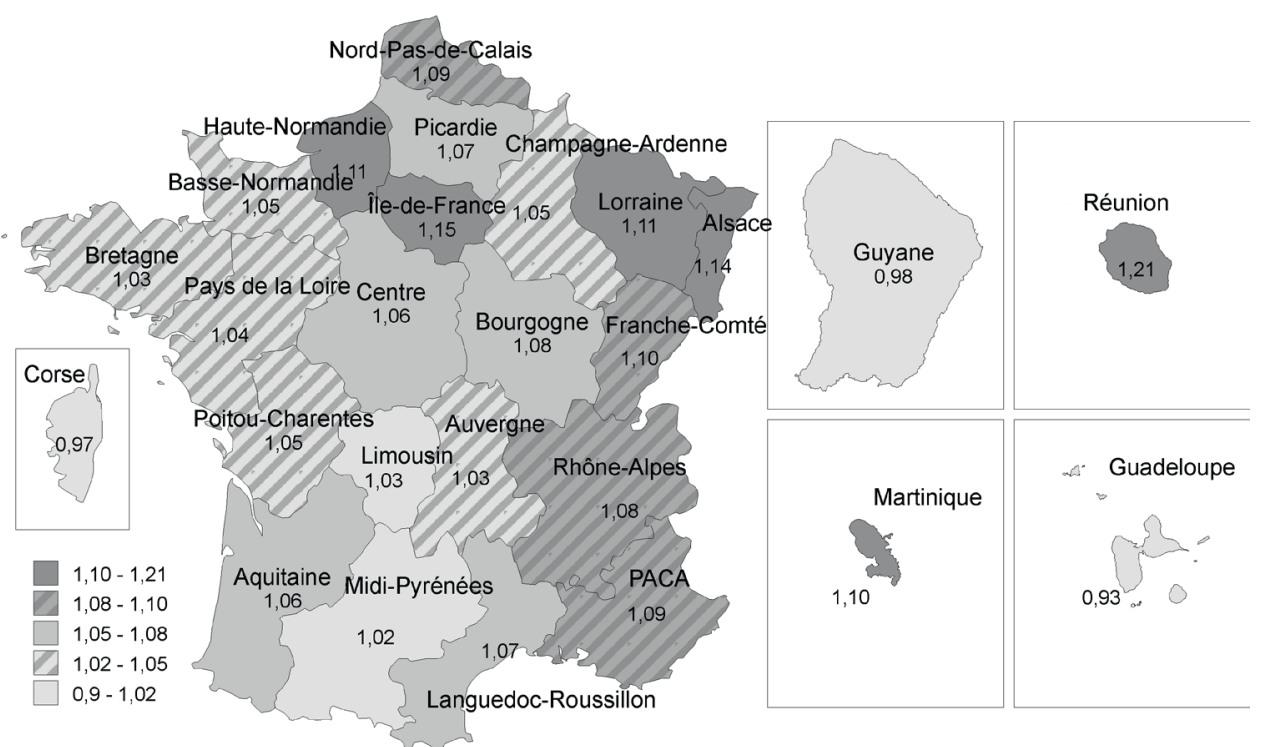

Ryc. 20. Stosunek średniej wartości liczby osób samozatrudnionych na 100 zatrudnionych w latach 2006-2008 do wartości tego współczynnika za lata 2010-2012

Źródło: opracowanie własne na podstawie danych DGCIS 

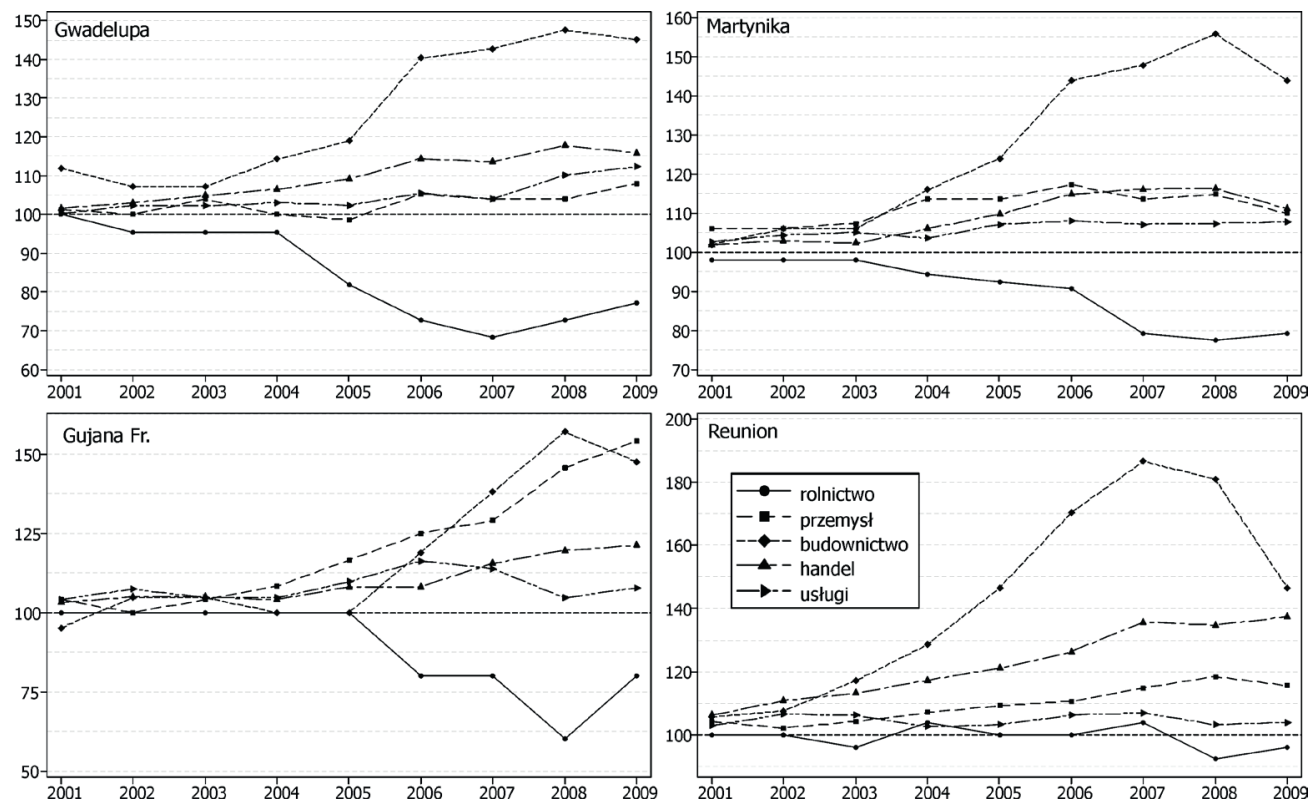

Ryc. 21. Zmiana wielkości zatrudnienia w departamentach zamorskich Francji w latach 2001-2009 $(2000$ r. $=100)$

Źródło: opracowanie własne na podstawie danych DGCIS
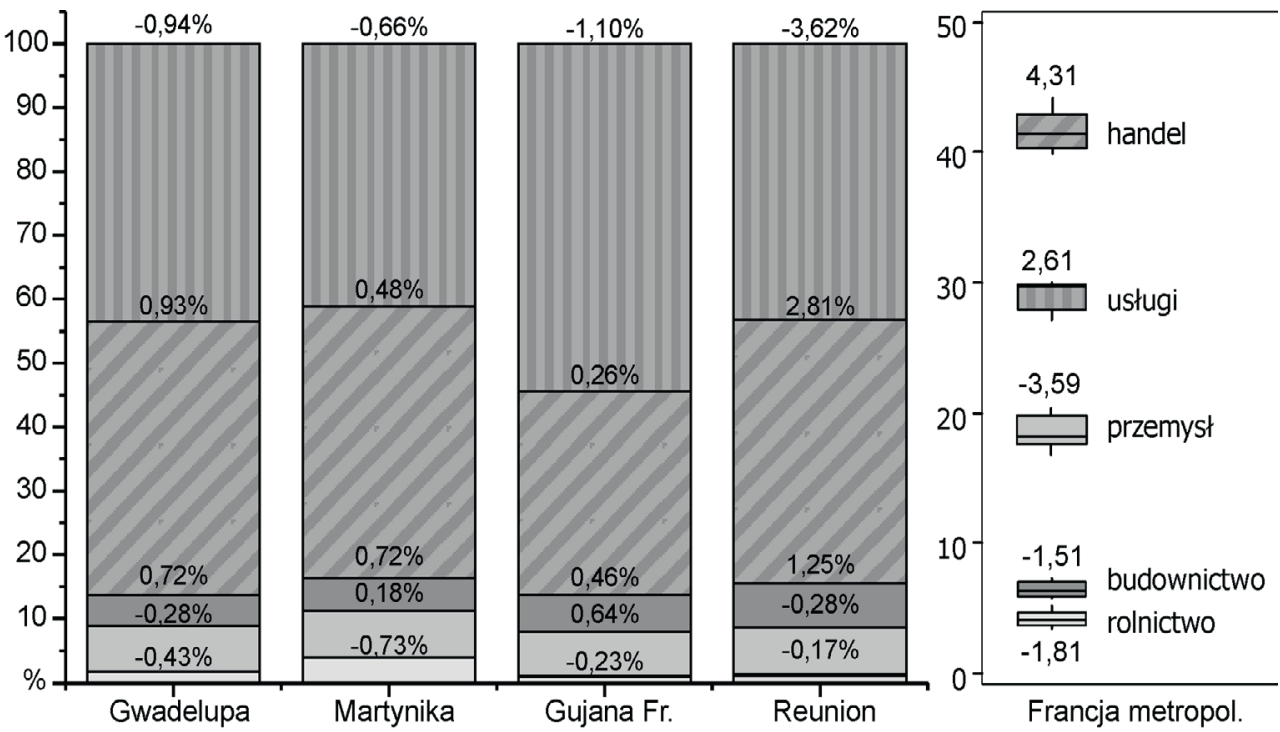

Ryc. 22. Zmiana wartości zatrudnionych w głównych sektorach gospodarki latach 2002-2009 $(2001$ r. $=100)$

Źródło: opracowanie własne na podstawie danych DGCIS 
W podsumowaniu zmian zachodzących w wyniku kryzysu światowego na rynku pracy w departamentach zamorskich Francji dokonano zestawienia średniorocznego tempa zmian wielkości zatrudnienia oraz zmian wartości dodanej w latach kryzysu 2008-2011. Otrzymane wartości odniesiono do danych dla Francji metropolitalnej. Porównując otrzymane wyniki, można zauważyć, że tylko w przypadku usług departamenty Gwadelupa i Gujana Francuska odnotowały mniejszy wzrost niż regiony metropolitalne. Ogólnie, poza Gujaną Francuską, tempo wzrostu zatrudnienia w pozostałych departamentach zamorskich było większe niż na kontynencie. Największy wzrost zatrudnienia w DROM w okresie kryzysu stwierdzono w rolnictwie, co mogło być powodowane utratą pracy i wzrostem bezrobocia ukrytego w rolnictwie. W przypadku wartości dodanej niższy wzrost w stosunku do metropolii wystąpił w sektorach: rolnictwa, informacyjnym i komunikacyjnym oraz we wspomnianej rozrywce i innych usługach. Natomiast największy wzrost stwierdzono w przemyśle i budownictwie. Wypada zatem odnotować, że pod względem tempa zmian najlepiej w okresie kryzysu rozwijała się gospodarka Réunion (wartości tempa wzrostu zatrudnienia i wartości dodanej powyżej wartości dla Francji metropolitalnej). W przypadku Martyniki i Gwadelupy większość sektorów gospodarki odnotowała bardziej natężony wzrost zatrudnienia niż na kontynencie przy niższym tempie zwyżki wartości dodanej. Natomiast w Gujanie Francuskiej wzrost zatrudnienia był niższy niż w Europie, podczas gdy większość sektorów odnotowało zauważalne zwiększenie wartości dodanej.

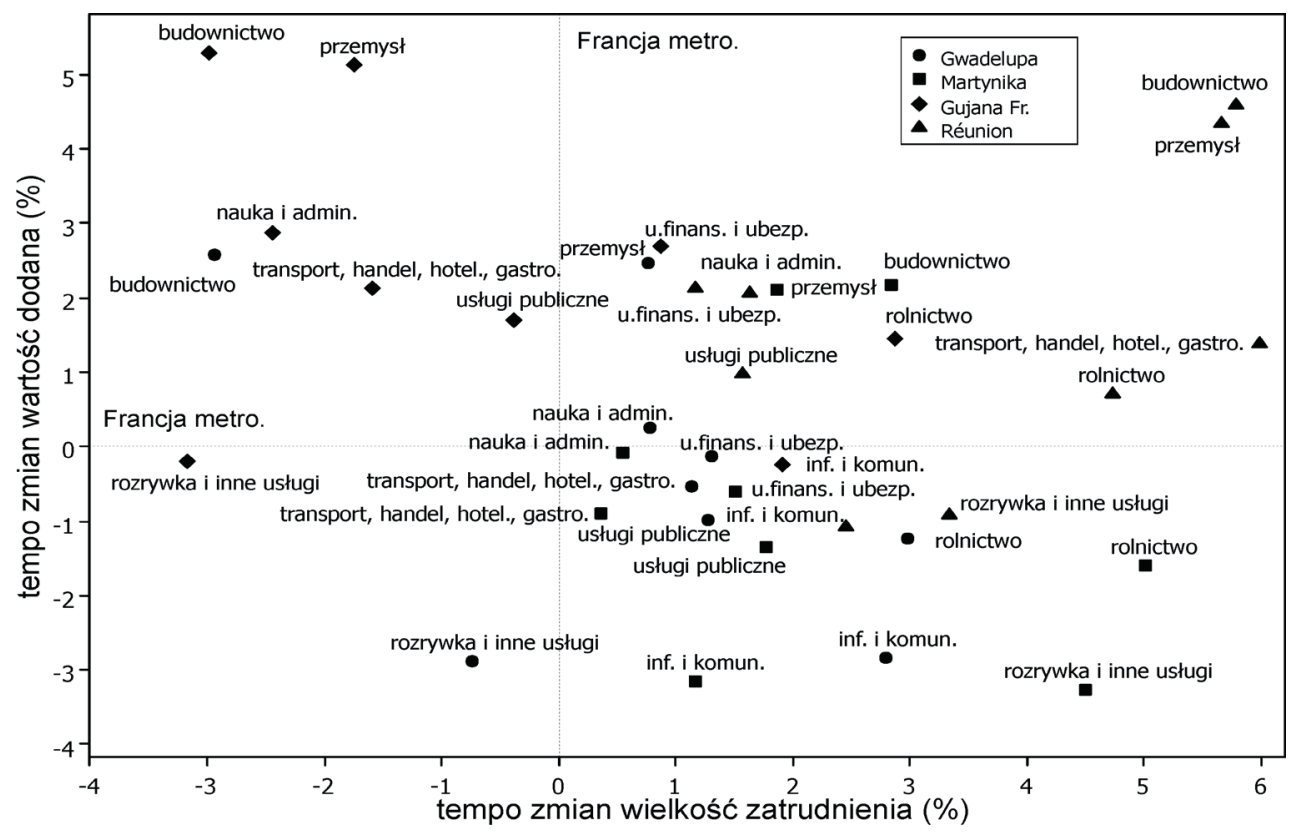

Ryc. 23. Średnioroczne tempo zmian wielkości zatrudnienia w departamentach zamorskich Francji na tle Francji metropolitalnej oraz w zestawieniu ze średnim tempem zmian wartości dodanej w latach 2008-2011 (wykres: średnie tempo zmian dla Francji metropolitalnej =0) 


\section{Podsumowanie}

Na podstawie przeprowadzonych badań można potwierdzić wpływ światowego kryzysu finansowego na struktury gospodarcze zamorskich departamentów Francji. W wyniku kryzysu francuskie terytoria zależne odnotowały wzrost bezrobocia i liczby upadłości firm, co wpłynęło pośrednio na zainteresowanie samozatrudnieniem. Jednakże powyższe procesy wykazywału odmienny przebieg w poszczególnych departamentach i różniły się od mechanizmów zachodzących na kontynencie. Ogólnie można zaryzykować tezę o efekcie „odwrócenia" trendów gospodarczych w wyniku zaistniałej dekoniunktury. W wielu przypadkach regiony lepiej rozwinięte $\mathrm{w}$ większym stopniu odczuły niekorzystne skutki kryzysu, aniżeli regiony słabiej rozwinięte i peryferyjne. Związane to było głównie z dużym udziałem przemysłu i rzemiosła w progresywnych regionach Francji, a zatem tych sektorów, które na kontynencie odczuły największą recesję. Natomiast w regionach rozwiniętych, pomimo większych wahań analizowanych wskaźników gospodarczych, zmiany te nie były tak jednokierunkowe jak we Francji metropolitalnej, gdzie większość regionów wykazywała podobne wartości zmian w warunkach kryzysu. Gospodarka departamentów zamorskich Francji stanowi zatem specyficzny typ lokalnej ekonomii, podobnie jak w przypadku regionów Île-de-France i Korsyka w Europie. W departamentach kryzys bez wątpienia spowolnił rozwój, lecz go nie zatrzymał. Trzeba wspomnieć, że ekonomia DROM należy do młodych rozwijających się gospodarek, które mogą liczyć na wsparcie UE. Dzięki temu od połowy XX w. nastąpił siedmiokrotny wzrost poziomu życia. Pociąga to za sobą ożywienie popytu na lokalnym rynku, co widać w szybkim rozwoju budownictwa angażującego niemal 10\% siły roboczej DROM. Innym atutem departamentów zamorskich Francji jest rozwój przemysłu, w tym przemysłu wysokich technologii, czego bardzo dobrym przykładem jest np. Gujana Francuska. Ponadto dynamiczny wzrost znaczenia sektora turystycznego w znaczący sposób niwelował niekorzystny wpływ globalnej recesji gospodarczej. A sektor ten-w świetle badań M. Zdon-Korzeniowskiej i T. Rachwała (2011) - jest stosunkowo odporny na zjawiska kryzysowe. Gospodarka departamentów zamorskich Francji, pomimo słabszych wyników ekonomicznych, wykazuje silniejsze niż we Francji metropolitalnej tempo wzrostu, które z czasem powinno obejmować coraz bardziej zaawansowane sfery gospodarcze.

\section{Literatura \\ References}

Almar, N. (2012). La parole libérée sur le web. Le cas de la crise antillaise de 2009. W: Ch. Benavides, N. Fejic, C. Palmiste (red.). Libertés et oppressions. Approches pluridisciplinaires, Paris: L'harmattan, 65-76.

Anagnostopoulos L. (2013). Entreprises: record de faillites en 2013. Lyon Capitale. Pozyskano $\mathrm{z}$ http://www.lyoncapitale.fr/Journal/France-monde/Actualite/Economie/ Entreprises-record-defaillites-en-2013.

Bauer, K. (2010). Kryzys finansowy a restrukturyzacja przedsiębiorstw w stanie upadłości. Prace Komisji Geografii Przemystu Polskiego Towarzystwa Geograficznego, 15, 209-218. 
Bernabé J., Chamoiseau P., Confiant R. (1993). Eloge de la trolit. Paris: Gallimard French.

Dąbrowski, K. (2010). Przedsiębiorczość i edukacja jako strategie profesjonalistów na czas kryzysu. Przedsiębiorczość - Edukacja, 6, 493-498.

Desse, M. (2013). Les îles de la Caraïbe: enjeux et perspectives. Paris: L'Harmattan.

Dorocki, S. (2011). Wpływ kryzysu gospodarczego na przemiany struktur regionalnych Francji. Prace Komisji Geografii Przemystu Polskiego Towarzystwa Geograficznego, 17, 67-86.

Dorocki, S., Brzegowy, P. (2012). Regionalne zróżnicowanie kształcenia we Francji w aspekcie rozwoju przedsiębiorczości departamentów zamorskich. Przedsiębiorczość - Edukacja, 8, 229-258.

Dorocki, S., Brzegowy, P. (2013a). Rozwój przemysłu turystycznego departamentów Francji zamorskiej w warunkach światowego kryzysu gospodarczego. Przedsiębiorczość - Edukacja, 9.

Dorocki, S., Brzegowy, P. (2013b). Wpływ polityki innowacyjnej na rozwój przemysłu zaawansowanej technologii w departamentach Francji zamorskiej. Prace Komisji Geografii Przemystu Polskiego Towarzystwa Geograficznego, 21, 294-315.

Dorocki, S., Świętek, A. (2013). Działania wybranych instytucji publicznych na rzecz wsparcia przedsiębiorczości w dobie kryzysu gospodarczego w Polsce. Przedsiębiorczość -Edukacja, 9.

Kilar, W. (2011). Wpływ kryzysu na funkcjonowanie korporacji Panasonic. Prace Komisji Geografii Przemystu Polskiego Towarzystwa Geograficznego, 17, 187-196.

Kilar, W., Kurek, S., Rachwał, T. (2013). Kształtowanie kompetencji osobistych i społecznych w szkolnictwie zawodowym dla sektora handlu detalicznego w świetle opinii partnerów społecznych. Przedsiębiorczość - Edukacja, 9.

Kurek, S., Rachwał, T. (2010). Założenia i wstępne wyniki europejskiego projektu badawczego FIFOBI w zakresie kształtowania kompetencji uczniów gimnazjum do prowadzenia działalności gospodarczej. Przedsiębiorczość - Edukacja, 6, 472-485.

Labosse L. (2010). La crise modifie la carte du chômage en Rhône-Alpes. La Lettre Analyses, 127.

Lacroix S. (2012) L'impact de la crise sur l'emploi dans les regions. Pozyskano z http://www.revuepolitique.fr/blog/limpact-de-la-crise-sur-lemploi-dans-les-regions/.

Lagoutte, Ch. (2013). Les jeunes diplômés font les frais de la crise. Le Figaro. Pozyskano z http://etudiant.lefigaro.fr/les-news/actu/detail/article/les-jeunes-diplomes-font-les-frais-de-la-crise-2782/

Le nombre de chômeurs augmente de $0,1 \%$ en octobre à la Réunion. Réunion 1ère. Pozyskano z http://reunion.la1ere.fr/2013/11/28/le-nombre-de-chomeurs-augmente-de-01-en-octobre-la-reunion-89359.html.

Ledain, N. (2013). Chiffres de pôle emploi: ça monte aussi en Guadeloupe. Guadeloupe 1ère. Pozyskano z http://guadeloupe.la1ere.fr/2013/12/26/chiffres-de-pole-emploi-ca-monte-aussi-enguadeloupe-96679.html.

Priollaud, F.-X., Siritzky, D. (2008). Traité de Lisbonne. Texte et commentaire, article par article, des nouveaux traités européens (TUE-TFUE). Paris: La Documentation Française.

Rachwał, T. (2011). Wpływ kryzysu na zmiany produkcji przemysłowej w Polsce. Prace Komisji Geografii Przemystu Polskiego Towarzystwa Geograficznego, 17, 99-113.

Raźniak, P. (2013). Globalne powiązania metropolii europejskich - próba typologii. Studia Miejskie, 9, 83-94.

Raźniak, P., Winiarczyk-Raźniak, A. (2013). Spatial distribution and differences in migration patterns and revenues of gminas in the Kraków Metropolitan Area. Bulletin of Geography. Socioeconomic Series, 19, 73-86.

Schaeffer F. (2012). Les défaillances de PME ont bondi au printemps. Les Echos, 21223, 3. Pozyskano $\mathrm{z}$ http://www.lesechos.fr/10/07/2012/LesEchos/21223-014-ECH_les-defaillances-de-pme-ont-bondi-au-printemps.htm.

Tempier A. (red.) (2013). Une conjoncture corse toujours dégradée. Insee Corse conjoncture, 3. Pozyskano z: http://www.insee.fr/fr/themes/document.asp?reg_id=6 \&ref_id=20194.

Tokarski, A. (2010). Upadłość jako naturalny regulator konkurencji i przedsiębiorczości w gospodarce rynkowej na przykładzie gospodarki polskiej. Przedsiębiorczość - Edukacja, 6, 78-91. 
Zdon-Korzeniowska, M., Rachwał, T. (2011). Turystyka w warunkach światowego kryzysu gospodarczego. Prace Komisji Geografii Przemystu Polskiego Towarzystwa Geograficznego, 18, 116-128. Zioło, Z. (2011). Wpływ światowego kryzysu na tempo wzrostu gospodarki i światowych korporacji. Prace Komisji Geografii Przemystu Polskiego Towarzystwa Geograficznego, 17, 9-32.

Sławomir Dorocki, absolwent studiów z zakresu geografii społeczno-ekonomicznej Uniwersytetu Pedagogicznego w Krakowie, doktor nauk humanistycznych w dyscyplinie historia (Instytut Europeistyki, Uniwersytet Jagielloński). Adiunkt w Instytucie Geografii Uniwersytetu Pedagogicznego w Krakowie. Zainteresowania badawcze skupiają się wokół problematyki regionów i procesów regionalizacji społeczno-gospodarczej, ze szczególnym uwzględnieniem zróżnicowania przestrzeni europejskiej oraz procesów integracji europejskiej i uwarunkowań historycznych.

Sławomir Dorocki, graduated from Pedagogical University in Krakow with MA degree in geography, Ph.D. in history (Institute of European Studies of the Jagiellonian University). Adiunkt (assoc. professor) at Pedagogical University of Cracow, Institute of Geography. His research interests are tied with regional problems and processes of socio-economic regionalization, with particular emphasis on the diversity of Europe, processes of European integration and historical conditions.

\section{Adres/adress:}

Uniwersytet Pedagogiczny w Krakowie

Instytut Geografii

Zakład Przedsiębiorczości i Gospodarki Przestrzennej

ul. Podchorążych 2, 30-084 Kraków, Polska

e-mail: sdorocki@up.krakow.pl

Pawel Brzegowy, absolwent Instytutu Nauk Politycznych i Stosunków Międzynarodowych Uniwersytetu Jagiellońskiego, doktorant w Instytucie Geografii Uniwersytetu Pedagogicznego im. Komisji Edukacji Narodowej w Krakowie. Główne zainteresowania badawcze dotyczą historii społecznej i gospodarczej departamentów i wspólnot Francji pozaeuropejskiej oraz galicyjskiej kultury zdrojowiskowej w XIX i XX w.

Pawel Brzegowy, graduate of the Institute of Political Studies and International Relations at the Jagiellonian University, doctoral student at the Faculty of Geography at the Pedagogical University of Cracow named after the National Education Commission. Main research interests focused on social and economic history of extra-European France departments and communities.

\section{Adres/adress:}

Uniwersytet Pedagogiczny w Krakowie

Instytut Geografii

ul. Podchorążych 2, 30-084, Kraków, Polska

e-mail: pawel.brzegowy@uj.edu.pl 